\title{
Gas-emission craters of the Yamal and Gydan peninsulas: A proposed mechanism for lake genesis and development of permafrost landscapes
}

\author{
Yury A. Dvornikov ${ }^{1}$ (D) । Marina O. Leibman ${ }^{1,2}$ (D) | Artem V. Khomutov ${ }^{1,2}$ (D) । \\ Alexander I. Kizyakov ${ }^{3}$ (D) । Petr Semenov ${ }^{4}$ । Ingeborg Bussmann ${ }^{5}$ (D) | Evgeny M. Babkin ${ }^{1}$ । \\ Birgit Heim $^{6}$ (D) | Alexey Portnov ${ }^{7}$ (D) | Elena A. Babkina ${ }^{1}$ | Irina D. Streletskaya ${ }^{3}$ (I) । \\ Antonina A. Chetverova ${ }^{8,9}$ | Anna Kozachek ${ }^{8}$ (D) | Hanno Meyer ${ }^{6}$ (D)
}

\footnotetext{
${ }^{1}$ Earth Cryosphere Institute of Tyumen Scientific Centre SB RAS, Tyumen, Russia

${ }^{2}$ Tyumen State University, Tyumen, Russia

${ }^{3}$ Lomonosov Moscow State University, Moscow, Russia

${ }^{4}$ I.S. Gramberg All-Russia Scientific Research Institute of Geology and Mineral Resources of the World Ocean (VNIIOkeangeologia), SaintPetersburg, Russia

${ }^{5}$ Alfred Wegener Institute Helmholtz Centre for Polar and Marine Research, Germany

${ }^{6}$ Alfred Wegener Institute Helmholtz Centre for Polar and Marine Research, Potsdam, Germany

${ }^{7}$ School of Earth Sciences, The Ohio State University, Columbus, Ohio

${ }^{8}$ Arctic and Antarctic Research Institute, SaintPetersburg, Russia

${ }^{9}$ Saint-Petersburg State University, Institute of Earth Sciences, Saint-Petersburg, Russia
}

\section{Correspondence}

Yury Dvornikov, Earth Cryosphere Institute, Tyumen Scientific Centre, Siberian Branch of Russian Academy of Sciences, Tyumen, Russia. Email: ydvornikow@gmail.com

Funding information

Russian Science Foundation, Grant/Award Number: 16-17-10203; Russian Foundation for Basic Research (RFBR), Grant/Award Numbers: 18-05-60222 and 18-05-60080

\begin{abstract}
This paper describes two gas-emission craters (GECs) in permafrost regions of the Yamal and Gydan peninsulas. We show that in three consecutive years after GEC formation (2014-2017), both morphometry and hydrochemistry of the inner crater lakes can become indistinguishable from other lakes. Craters GEC-1 and AntGEC, with initial depths of 50-70 and 15-19 m respectively, have transformed into lakes 3-5 m deep. Crater-like depressions were mapped in the bottom of 13 out of 22 Yamal lakes. However, we found no evidence that these depressions could have been formed as a result of gas emission. Dissolved methane $\left(\mathrm{dCH}_{4}\right)$ concentration measured in the water collected from these depressions was at a background level (45 ppm on average). Yet, the concentration of $\mathrm{dCH}_{4}$ from the near-bottom layer of lake GEC-1 was significantly higher (824-968 ppm) during initial stages. We established that hydrochemical parameters (dissolved organic carbon, major ions, isotopes) measured in GEC lakes approached values measured in other lakes over time. Therefore, these parameters could not be used to search for Western Siberian lakes that potentially resulted from gas emission. Temperature profiles measured in GEC lakes show that the water column temperatures in GEC-1 are lower than in Yamal lakes and in AntGEC - close to values of Gydan lakes. Given the initial GEC depth $>50 \mathrm{~m}$, we suggest that at least in GEC-1 possible re-freezing of sediments from below might take place. However, with the present data we cannot establish the modern thickness of the closed talik under newly formed GEC lakes.
\end{abstract}

\section{KEYWORDS}

gas-emission craters, gydan, lakes, methane, yamal

\section{1 | INTRODUCTION}

During the Quaternary, the West Siberian Arctic underwent consecutive glacial-interglacial and marine transgression-regression stages.
Glacial periods characterized by significantly lower air temperatures allowed the development of thick onshore and offshore permafrost. ${ }^{1}$ Maximum permafrost development occurred during the Last Glacial Maximum ( 20 ky BP). The modern Kara Sea shelf (>120 m b.s.l.) 
was in suberial conditions and therefore the Yamal peninsula was characterized by a more continental climate. On the Yamal peninsula, terrestrial permafrost has been sustained throughout the Late Pleistocene, although ground temperatures increased during the Holocene climatic optimum, and temperatures then decreased following this stage ( $<3$ ky BP). Therefore, the majority of modern permafrost on the Yamal peninsula is of Late Pleistocene age ( $\leq 20 \mathrm{ky} \mathrm{BP})$. The Yamal-Gydan area is today characterized by continuous permafrost up to $450 \mathrm{~m}$ thick with ground temperatures varying between -1 and $-9^{\circ} \mathrm{C}$ and with average ice content $30-50 \%$ of the total volume. ${ }^{2}$ A specific feature of the cryolithological conditions of the area is a wide distribution of tabular ground ice (TGI) and cryopegs in the geological section., ${ }^{3,4}$ Being impermeable to gas, permafrost generated significant gas storage in the form of free gas and in the form of gas hydrates. Recent climate warming in the $\operatorname{Arctic}^{5}$ has led to increases in ground temperatures and active layer thickness, ${ }^{6}$ triggering release of shallow gas accumulations from the upper permafrost layer.

For the first time in the terrestrial permafrost environment, gas emission craters (GECs) have been observed on the Yamal $^{7}$ and Gydan ${ }^{8}$ peninsulas in summer and autumn 2014 (Figure 1). The Yamal GEC (69.9711 N, 68.3703다 $), 42 \mathrm{~km}$ from Bovanenkovo gas field, was named GEC-19 and the Gydan GEC near Antipayuta settlement $\left(69.7946 \mathrm{~N}, 75.035^{\circ} \mathrm{E}\right)$ was named AntGEC. ${ }^{8}$ Initially, these two permafrost-related features were deep and relatively narrow cylinder-shaped depressions with subvertical frozen walls and a funnel-shaped top. ${ }^{9}$ The first field expeditions to GEC-1 in 2014 described the surrounding landscape of the area, provided morphometric descriptions of GEC-1 and proposed an origin of this landform as resulting from the emission of methane from permafrost., ${ }^{7-11}$ Later, more accurate morphometric parameters of GEC-1 were defined. ${ }^{12,13}$ Geophysical surveys using electrical-resistivity tomography techniques revealed a possible layer of gas hydrates at a depth of $60-80 \mathrm{~m}$ and established the base of permafrost at depths of $160-180$ m surrounding GEC-1. ${ }^{14}$

Decomposition of gas hydrates and associated explosive gas emission was proposed as one of explanantions for this crater's appearance. ${ }^{15}$ An alternative hypothesis proposed that GEC-1 formed as a result of the collapse of a large pingo formed after lake drainage allowing the existing sub-lake talik (a layer of year-round unfrozen ground in permafrost areas) to re-freeze accompanied by the growth of cryogenic hydrostatic pressure. ${ }^{16}$ Based on SPOT-5 and Landsat- 8 satellite images, the eruption date of GEC-1 was narrowed to an interval between October 9 and November 1, 2013. ${ }^{12}$ According to information provided by the local Nenets community, AntGEC formed on October 27, 2013. ${ }^{17}$ Satellite data analysis revealed that a mound 45-58 $\mathrm{m}$ in diameter and 5-6 $\mathrm{m}$ in height existed before the formation of GEC-1, and was named mound-predecessor (MP). ${ }^{12}$ Before AntGEC formation, MP had base diameter of $20 \mathrm{~m}$ and height of only $2 \mathrm{~m}$. Expansion of this mound led to a blowout of ground ice and sediments over a radius of up to $300 \mathrm{~m} .^{8,12,17-19}$ Therefore, such blowouts
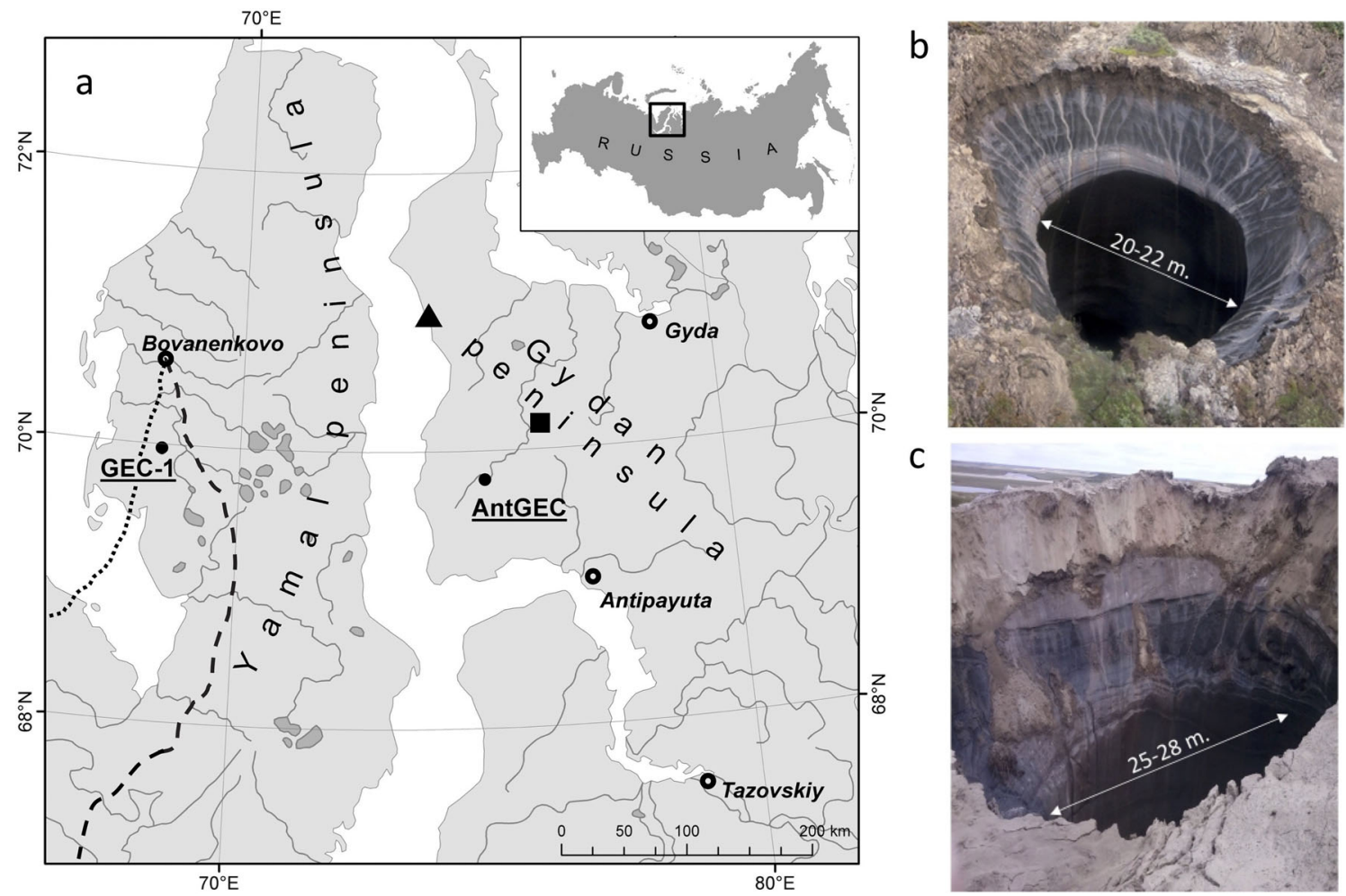

FIGURE 1 Studied objects: (b) map of GEC-1 and AntGEC location; (b) photo of GEC-1 taken from helicopter in July 2014 by M. O. Leibman; (c) photo of AntGEC October 21, 2013 by K. S. Okotetto. Dashed line -Obskaya-Bovanenkovo railway, dotted line -Bovanenkovo-Ukhta gas pipeline, black rectangle - planned development of Gydanskoe gas field, black triangle - planned development of Salmanovskoe gas field and Arctic LNG-2 infrastructure [Colour figure can be viewed at wileyonlinelibrary.com] 
can be hazardous for existing infrastructure on the Yamal peninsula and planned infrastructure on the Gydan peninsula (Figure 1). For example, GEC-1 is located near the Bovanenkovo-Ukhta gas pipeline and Obskaya-Karskaya railway, as well as migration routes and camping places of indigenous reindeer herders. This makes the study of GECs critically important both for the scientific community and for future development of this region.

Ongoing GEC studies will help to identify areas of potential gas blowouts, which in turn will help to prevent possible infrastructure collapse and provide recommendations for industrial development in permafrost regions. Moreover, GEC studies will provide a significant contribution to a paleo-permafrost knowledge database, including novel insight into past evolution of permafrost landscapes of the West Siberian Arctic.

Lakes are abundant in Yamal and Gydan. Lakes cover on average $10 \%$ of the Yamal peninsula, ${ }^{20}$ reaching $20 \%$ on floodplains of large rivers such as Mordy-Yakha and Se-Yakha. ${ }^{21}$ About $90 \%$ of all lakes are small $\left(<1 \mathrm{~km}^{2}\right)$ water bodies. ${ }^{22}$ Since our first observations, it became evident that GECs could potentially evolve into new lakes, which would be unrecognizable from other lakes.,11 Despite the prevailing hypothesis that the majority of Yamal lakes have resulted from thermokarst processes, ${ }^{21}$ the occurrence of GEC features has allowed us to hypothesize that gas emission has played some role in the initial stages of lake formation on the Yamal and Gydan peninsulas during the Holocene. ${ }^{9}$ To test this hypothesis, we analyzed a number of hydrochemical parameters both for GEC lakes and other "normal" lakes of the Yamal and Gydan peninsulas in order to find similarities between them and to establish specific hydrochemical features of GEC lakes that could be used to search for other lakes that have possibly appeared as a result of gas emission. Hydrochemical features include methane concentration, isotopic signatures of the lake water, lake water chemistry and temperature regimes. Specifically, we wanted to test the following: if methane has played an important role in GEC occurrence, the methane source might have provided elevated dissolved methane concentrations in a newly formed lake; how strong are the dynamics of methane concentration in GEC lakes over the years and what is the potential source of methane?; what is the main water source in GEC lakes thawed ground ice or atmospheric precipitation and do the water isotopic composition and water chemistry differ from other lakes?; what are the current temperatures of the GEC lake water and how does this influence further talik development under GEC lakes or, otherwise, allow the sediments infilling these lakes to be re-frozen? It was important to trace the dynamics of hydrochemical parameters of GEC lakes which may also contribute to the mentioned research question regarding the origin of lakes in Western Siberian as we do not know how fast can GEC lakes can come to resemble a "normal lake" in terms of hydrochemistry. Apart from the hydrochemical parameters, we have also compared detailed bathymetry of GEC lakes with the bathymetry of 22 Yamal lakes to find the evidence that gas emissions have occurred within modern basins of existing lakes on the Yamal peninsula. Since the initial GEC are clearly a very dynamic objects in terms of geomorphology, we also present the evolution of GEC-1, from the initial void (summer 2014) to the modern shallow lake (summer 2017).

\section{2 | MATERIALS AND METHODS}

\section{1 | Bathymetry of GEC lakes and Yamal lakes}

Bathymetric surveys of GEC lakes were performed (2015, 2017 - GEC1, 2016 - AntGEC) to establish the bottom structure of newly formed basins and their dynamics. Bathymetric measurements were performed using a Humminbird 788cxi chartplotter (vertical accuracy $\pm 0.1 \mathrm{~m}$ ) with echo sounder and internal GPS receiver installed on a boat, in calm weather conditions, or by lead line. Source data were processed using HumView software: depth values were extracted at 5 second intervals, corrected for signal noise. Sounding point data were gridded in ESRI ArcGIS 10 to obtain bathymetric maps with a spatial resolution of $1.5 \mathrm{~m}$. In addition to the GEC lakes, detailed bathymetric maps of 22 Yamal lakes were obtained during surveys in 2012-2017 using Humminbird 788cxi chartplotter (see ref. ${ }^{23}$ for details). Crater-like depressions in lake bottoms were delineated using bathymetric maps and slope maps. Depression slope polygons were defined as areas with a local, abrupt break in slope. The base of lake-bottom depressions (crater-like features) were delineated as flat areas with slopes of $0-2^{\circ}$.

\section{2 | Hydrochemistry of lake water}

Water samples for hydrochemical analyses were collected from newly formed GEC lakes and other Yamal and Gydan lakes within six winter and summer field campaigns during 2015-2017. Samples on Yamal were collected from 25 lakes located near Bovanenkovo settlement (Figure 1a). On Gydan, samples were collected from five and 14 lakes located near the settlements of Gyda and Tazovskiy respectively (Figure 1a).

Water samples were collected from both the upper layer $(0-30 \mathrm{~cm}$ below the water surface) of the water body and from the bottom layer (50-100 cm above the bottom) using a TD-Automatika hydrological water sampler. Bottom layer water samples were collected in most cases from the deepest areas of the lake, or in the lake center from the rubber boat. Samples from the upper layer were collected from the shore or using the boat. During winter field campaigns, lake ice drilling was performed to collect under ice water samples. In total, we collected 112 water samples from all lakes.

\subsection{1 | Dissolved methane concentration and isoto- pic composition $\left(\delta^{13} \mathrm{C}\right.$ and $\left.\delta \mathrm{D}\right)$}

Water samples for dissolved $\mathrm{CH}_{4}\left(\mathrm{dCH}_{4}\right)$ concentration were collected in $120 \mathrm{ml}$ glass serum bottles (flushed several times with sample water to ensure no contact with the atmosphere), capped with black rubber stoppers and sealed with an aluminum crimp. To prevent further microbial oxidation of $\mathrm{CH}_{4}, 65 \% \mathrm{HNO}_{3}$ was added to each sample. Glass bottles and rubber stoppers are relatively methane-tight and 
acidification of water samples results in good long-term sample preservation, ${ }^{24,25}$ but we cannot exclude the possibility that some $\mathrm{CH}_{4}$ was lost from the samples. $\mathrm{CH}_{4}$ concentrations were determined by gas chromatography in two laboratories: AWI Helgoland (2015) and VNIIOkeangeologia Saint-Petersburg in 2016-2017. Detailed information on the determination of $\mathrm{dCH}_{4}$ in water samples is given in Methods S1.

Carbon and hydrogen stable isotopes $\left(\delta^{13} \mathrm{C}, \delta \mathrm{D}\right)$ of $\mathrm{CH}_{4}$ were analyzed in ISOLAB b.v. with an Agilent 6890N GC (Agilent Technologies) interfaced to a Finigan Delta S IRMS using a Finigan GC-C II interface. Samples were calibrated regularly against a calibration standard and results are reported in permil vs. vPDB. Minimum $\mathrm{CH}_{4}$ concentrations for stable isotope measurements were approximately 40 and 300 ppm for carbon and hydrogen, respectively.

\subsection{2 | Stable water isotopes from Yamal, Gydan and GEC lakes}

Stable water isotopes $\left(\delta^{18} \mathrm{O}, \delta \mathrm{D}\right)$ were determined using mass spectrometry in two laboratories. Samples from 2015 were analyzed with a Finnigan MAT Delta-S mass spectrometer (AWI Potsdam). Samples from 2016 and 2017 were analyzed with a Picarro L2120-i analyzer at the Climate and Environmental Research Laboratory of Arctic and Antarctic Research Institute in Saint-Petersburg. Results were expressed in delta per mil notation $(\delta, \%$ ) relative to the Vienna Standard Mean Ocean Water (VSMOW) standard.

\subsection{3 | Dissolved organic carbon}

Water samples for dissolved organic carbon (DOC) were filtered through Whatman glass-fiber filters of $0.7 \mu \mathrm{m}$ pore size in the field and acidified with $\sim 30 \mu \mathrm{l}$ of $30 \% \mathrm{HCl}$ to prevent microbiological conversion. They were stored in cold conditions until processing with a Shimadzu TOC- $\mathrm{V}_{\mathrm{CPH}}$ in the Otto-Schmidt Laboratory (Saint-Petersburg) using the method of high-temperature combustion of nonpurgeable organic compounds (NPOCs). The accuracy of this method is $10 \%$. Additional information on DOC measurements and calculation in given in Methods S1.

\subsection{4 | Major ions}

Water samples for major ions were filtered through Sartorius cellulose-acetate (CA) filters of $0.45 \mu \mathrm{m}$ pore size. Samples for cation analysis were further acidified with $65 \% \mathrm{HNO}_{3}$ to prevent adsorptive accretion. Samples were then processed using ion-chromatography in the Otto-Schmidt Laboratory on a Methrom 761 Compact IC (20152016) and in VNIIOkeangeologia on a Methrom 940 Professonal IC Vario equipped with conductometry detector (2017). Results in the form of total concentrations ( $\mathrm{mg} \mathrm{L}^{-1}$ ) and equivalent \% (eq\%) were processed within RStudio software.

\subsection{5 | Temperature profiles}

Water temperature was measured every $2 \mathrm{~m}$ throughout the water column using a KrioLab logger with an accuracy of $\pm 0.1^{\circ} \mathrm{C}$. Temperature loggers were immersed in the water column for at least $20 \mathrm{~min}$ until complete stabilization of the temperature values.

\section{3 | RESULTS}

\section{1 | Bathymetry of GEC lakes}

Bathymetric maps were produced for GEC-1 lake based on 2015 (Figure 2a,b) and 2017 surveys (Figure 2c,d). The bathymetric map of AntGEC lake is based on 2016 survey (Figure 2e,f). In 2015, GEC-1 was characterized as a rounded, U-shaped hollow with a diameter of approximately $48 \mathrm{~m}$, a maximum depth of $23 \mathrm{~m}$, and we observed high ice content permafrost in the crater walls (Figure $2 \mathrm{~b}$ ). The lake surface area and water volume were 0.23 ha and $21,128 \mathrm{~m}^{3}$ respectively. By summer 2017, GEC-1 lake had become a drainage lake with an apparent inlet and outlet. The neighboring LK-001_CR lake (Figure 2a) provided the upstream source area (Figure 2c). Area and water volume in 2017 were 0.55 ha and $14,320 \mathrm{~m}^{3}$ respectively, the maximum measured depth was $4.9 \mathrm{~m}$, and the mean depth was $2.3 \mathrm{~m}$. The relatively flat bottom and steep sidewalls formed a bowl-shaped lake basin (Figure $2 \mathrm{~d})$.

In 2016, AntGEC lake (Figure 2e) was likewise characterized as a rounded U-shaped hollow (Figure $2 \mathrm{f}$ ). The maximum measured depth was only $3.6 \mathrm{~m}$ and mean depth $1.7 \mathrm{~m}$. Area and water volume were 0.099 ha and $1643 \mathrm{~m}^{3}$ respectively.

\section{2 | Bathymetry of Yamal lakes}

The maximum measured depth among the studied Yamal lakes (Table 1) varied broadly from $1.8 \mathrm{~m}$ in typical thermokarst lakes (eg LK-010) to $23.2 \mathrm{~m}$ in a lake located close to an area with near-surface TGI distribution (LK-015). Two of the lakes were deeper than $20 \mathrm{~m}$ (LK-008, LK015). However, the average measured depth in all lakes was $2.9 \mathrm{~m}$. Thirteen lakes had crater-like local depressions in their bottoms (Table 1). These depressions typically had steep slopes $\left(8.1^{\circ}\right.$ on average, although some slopes exceeded $36^{\circ}$ ) which is evident from depth profiles across the entire lake (Figure 3 ). The area of all the crater-like depressions within a lake including slopes was relatively small compared to the entire lake area (0.93-18.4\%, Table 1).

\subsection{Hydrochemistry of lake water}

\subsection{1 | Dissolved methane concentration and isoto- pic composition $\left(\delta^{13} \mathrm{C}\right.$ and $\left.\delta \mathrm{D}\right)$}

The concentration of $\mathrm{dCH}_{4}$ was obtained for Yamal lakes and GEC-1 lake in 2015 (summer) and 2017 (early spring, summer). $\mathrm{dCH}_{4}$ data are presented in Figure 4. In 2015, data for 23 Yamal lakes were obtained 

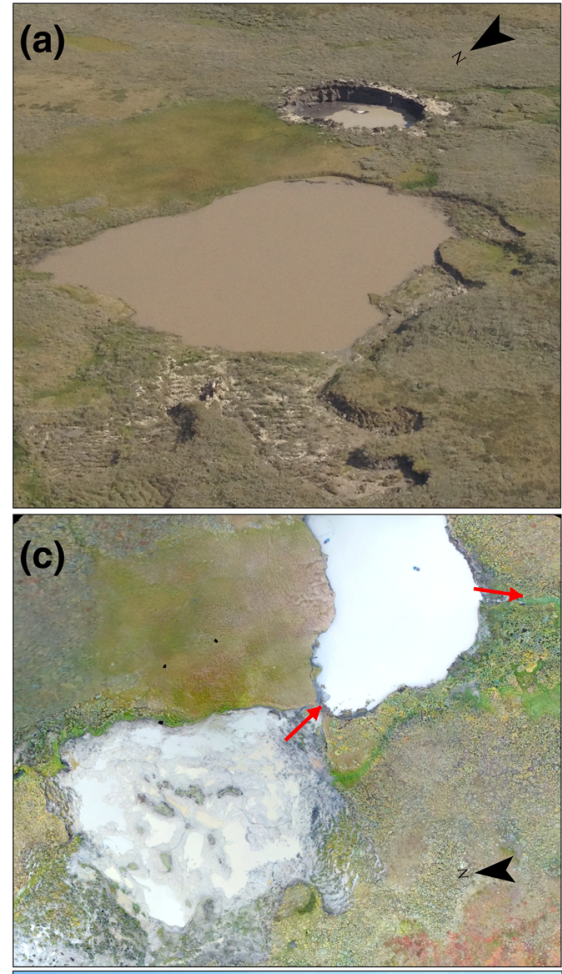

(e)
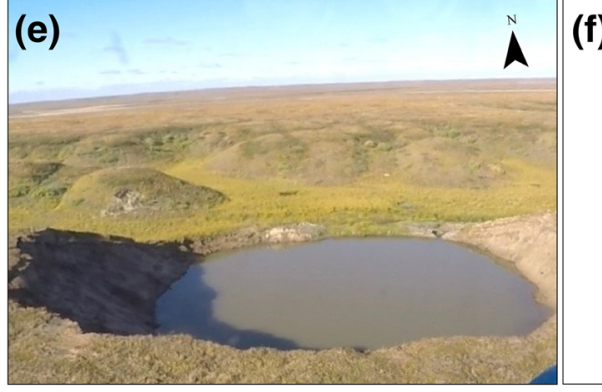

drainage pathways (b)

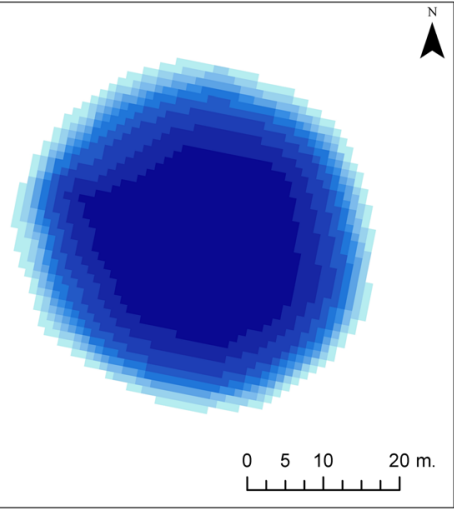

(d)

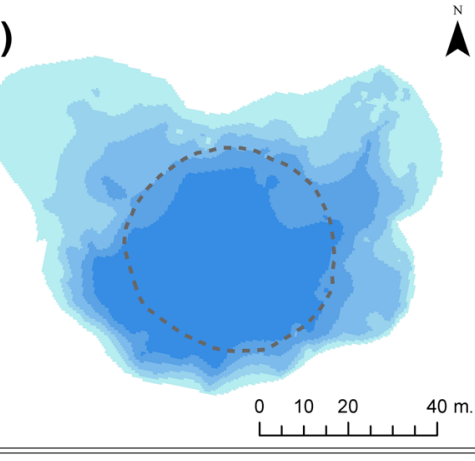

(f)

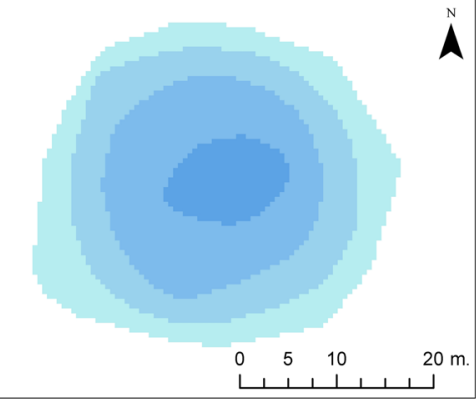

Depth, $m$

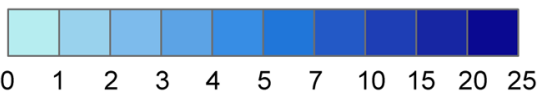

FIGURE 2 Photos and bathymetry of studied GEC lakes: (a) GEC-1 lake in the background, and lake LK-001 CR in the foreground, August 15, 2015 (photo Yu. Dvornikov); -(b,d) bathymetry of GEC-1 lake (September 1, 2015 and September 5, 2017, respectively), dashed grey circle on (d) shows GEC-1 area in 2015; -(c) UAV orthophoto map on September 5, 2017, red arrows represent the drainage pathway of the lake LK-001 CR; -(e) AntGEC lake on August 30, 2016 (photo A. Khomutov); -(f) bathymetry of AntGEC lake (August 30, 2016) [Colour figure can be viewed at wileyonlinelibrary.com] including nine lakes for which upper and bottom water were sampled. The concentration of $\mathrm{dCH}_{4}$ among all samples varied from 0 to $92 \mathrm{ppm}$ with a median value of $7.9 \mathrm{ppm}(n=23)$. Values for the bottom layer varied from 1 to $56 \mathrm{ppm}$ with a median value of $1.8 \mathrm{ppm}(n=9)$. Measured $\mathrm{dCH}_{4}$ concentrations in the GEC-1 lake water from the upper layer and from $14.4 \mathrm{~m}$ depth were 45 and 824 ppm, respectively.

In April 2017, water samples for six Yamal lakes were collected. In two lakes (LK-001, LK-006) water was sampled from two depths. Lake ice thickness varied from 1.25 to $1.5 \mathrm{~m}$ and the upper layer samples were collected from a depth of $3 \mathrm{~m}$. Samples from three lakes (LK002, LK-012, LK-016) were considered as bottom layer samples because of their shallow depths $(2,6,4.5 \mathrm{~m}$, respectively). Concentrations of $\mathrm{dCH}_{4}$ varied from 3.27 to $3.98 \mathrm{ppm}$ at $3 \mathrm{~m}$ depth $(n=3)$, and from 2.11 to $809.19 \mathrm{ppm}$ at the bottom $(3-15 \mathrm{~m})$ layer $(n=5)$. Concentrations of $\mathrm{dCH}_{4}$ measured in the GEC-1 lake water at depths of 3 and $8 \mathrm{~m}$ (ice thickness $1.3 \mathrm{~m}$ ) were 438 and 968 ppm, respectively.
In August-September 2017, water samples from 25 Yamal lakes were collected including 14 lakes with upper and bottom layer sampling. Concentrations of $\mathrm{dCH}_{4}$ varied from 6.24 to 37.03 ppm (median $12.86, n=25$ ) for upper layer samples, and from 3.03 to $100.58 \mathrm{ppm}$ (median 14.22, $n=14$ ) for the bottom layer samples (depth range 4$20 \mathrm{~m}$ ). Concentrations of $\mathrm{dCH}_{4}$ measured in the GEC-1 lake water from the upper layer and $4 \mathrm{~m}$ depth were 2.5 and $2.0 \mathrm{ppm}$, respectively.

Samples with $\mathrm{dCH}_{4}$ concentrations of at least $41 \mathrm{ppm}(n=10)$ were used to measure $\delta^{13} \mathrm{C}$ values and samples exceeding $100 \mathrm{ppm}$ $(n=5)$ were used to measure $\delta D$ values. In addition, three TGI samples from GEC-1 walls collected in September 2015 were added to this dataset. $^{26}$ Values of $\delta^{13} \mathrm{C}$ were within the range -84.5 to $-48.7 \%$ ( $n=13$ ), while $\delta D$ values ranged from -398 to $-258 \%$ o $(n=8$, Table 2). For GEC-1, TGI and water samples taken in this study revealed similar isotopic values for $\delta^{13} \mathrm{C}$ and $\delta \mathrm{D}(-70$ to $-85 \%$ and -364 to $-378 \%$ respectively). In contrast, in Yamal lakes $\delta^{13} \mathrm{C}$ and $\delta \mathrm{D}$ values 
TABLE 1 Characteristics of Yamal lakes: Bathymetry and bottom structure

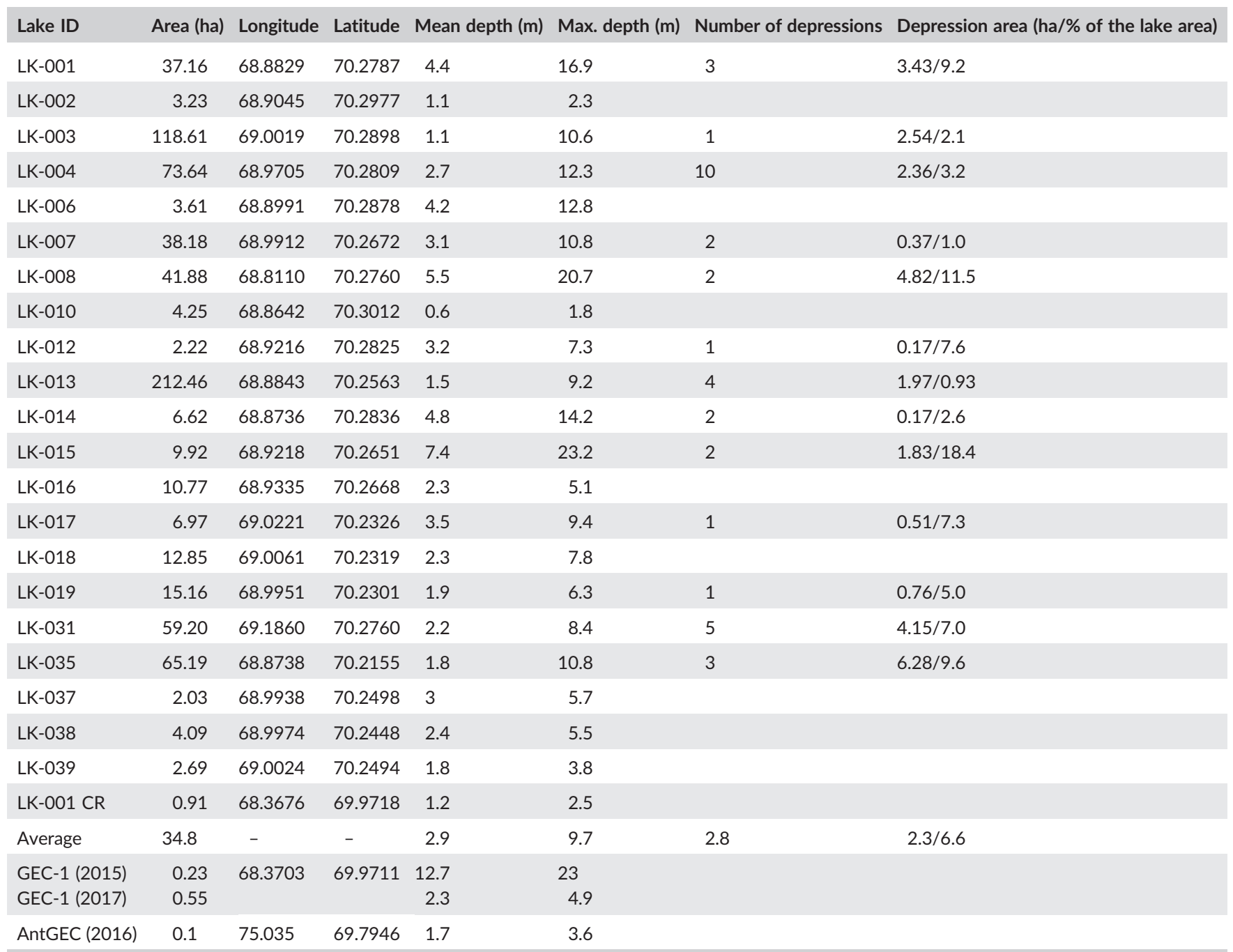

were heavier, ranging from -48 to $-67 \%$ ond from $-258 \%$ o to $-288 \%$ respectively. In 2015 , the $\delta^{13} \mathrm{C}$ values from GEC-1 water were similar to the surrounding TGI. In 2017, however, they were closer to the values obtained for Yamal lakes.

\subsubsection{Stable water isotopes from Yamal and Gydan lakes and GEC lakes}

Stable water isotope $\left(\delta^{18} \mathrm{O}, \delta \mathrm{D}\right)$ data show a wide range of values. Figure 5 shows $\delta^{18} \mathrm{O}$ and $\delta \mathrm{D}$ values plotted against VSMOW. Melted TGI has a lighter composition with $\delta^{18} \mathrm{O}$ values generally lower than $-20 \%$ and $\delta D$ values lower than $-140 \%$. In contrast, water collected from lakes of Central Yamal and Gydan typically has $\delta^{18} \mathrm{O}$ values higher than $-15 \%$ and $\delta D$ values generally higher than $-115 \%$ o (Figure 5). Water from GEC lakes occupies an intermediate position $\left(\delta^{18} \mathrm{O}\right.$ values between -20 and $-15 \%$ and $\delta D$ values between -150 and $-115 \%$ o). Water collected from GEC-1 in different years is characterized by a gradual progressive increase in the heavy fraction content from 2014 to 2017 (Figure 5). Water of AntGEC lake had $\delta^{18} \mathrm{O}$ values of -17.8 and $-17.6 \%$ and $\delta D$ values -136.9 and $-135.2 \%$ from $3 \mathrm{~m}$ depth and the upper layer, respectively.

\subsection{3 | Dissolved organic carbon}

The concentration of DOC in GEC-1 lake water was $50.3 \mathrm{mg} / \mathrm{L}$ in September 2015 samples. It decreased to $12.9 / 13.3 \mathrm{mg} / \mathrm{L}$ (upper layer/bottom layer) in April 2017, and further decreased to9.1/ $9.3 \mathrm{mg} / \mathrm{L}$ in September 2017 (only 18.3\% of the 2015 value).

DOC in Yamal lakes varied from 3.5 to $7.3 \mathrm{mg} / \mathrm{L}(n=24)$ in 2015 , from 3.7 to $36 \mathrm{mg} / \mathrm{L}$ in April 2017 and from 2.7 to $5.1 \mathrm{mg} / \mathrm{L}$ in summer 2017. No significant difference in DOC concentration was found within the water column of Yamal lakes: $\pm 0.4, \pm 0.8$ and $\pm 1.3 \mathrm{mg} / \mathrm{L}$ in August 2015, April 2017 and August-September 2017 respectively. Lower DOC concentrations were measured in lakes in summer 2017 

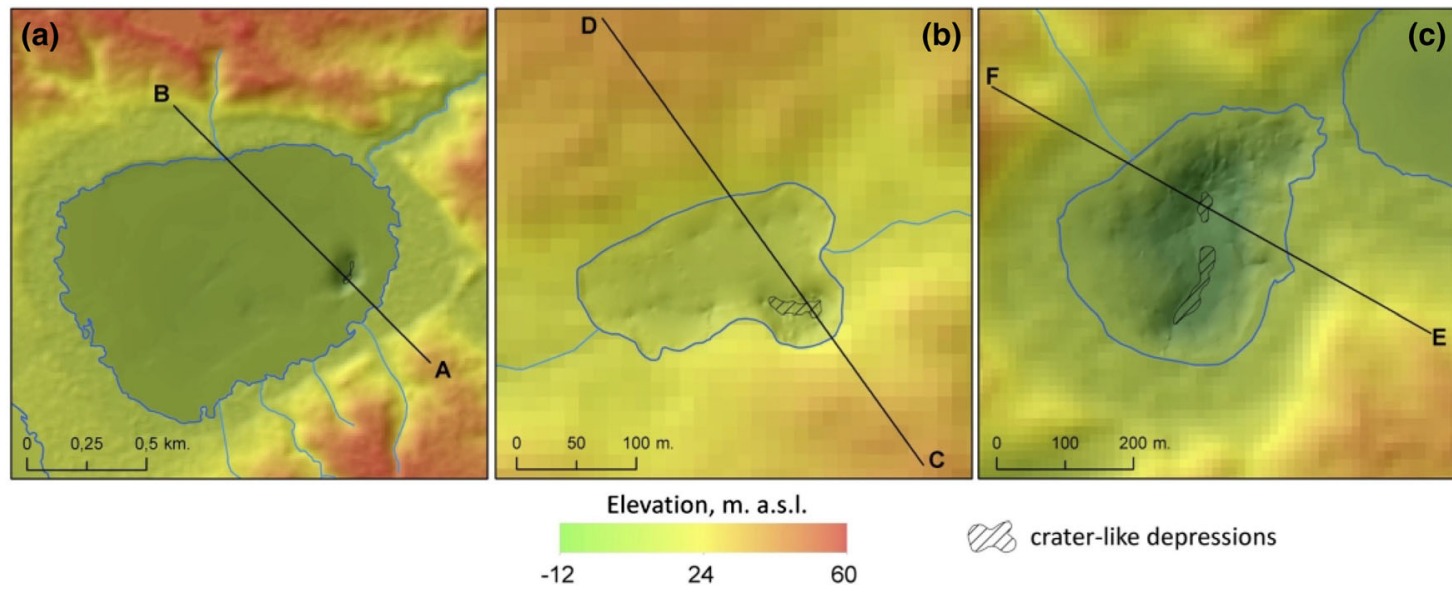

(d)

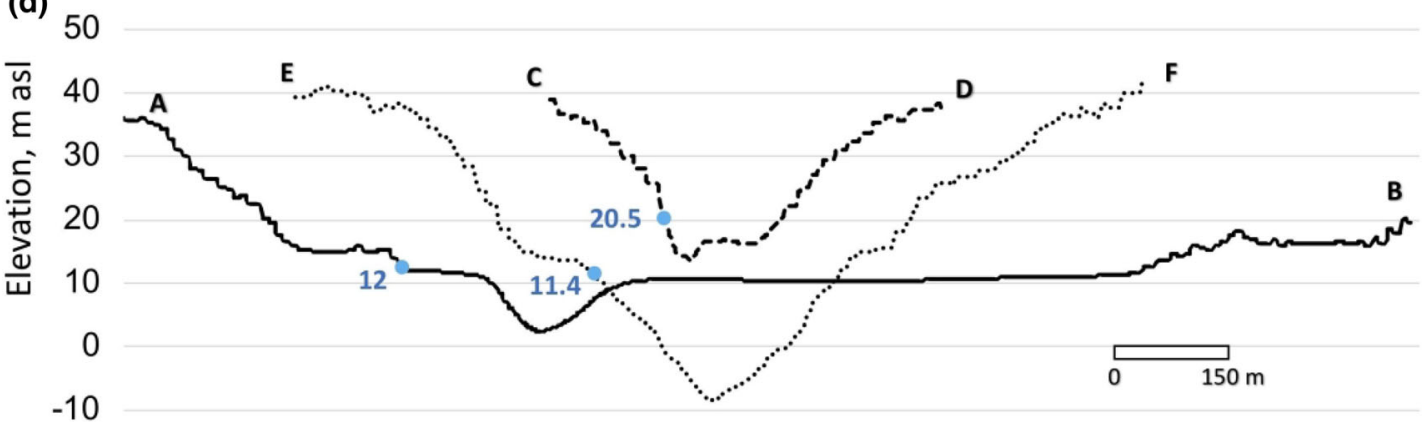

FIGURE 3 Digital terrain models of lake basins and catchments: -(a,b,c) lakes LK-003, LK-012 and LK-015, respectively (Table 1), elevations are given in Baltic height system; (d) lake depth profiles, blue dots and numbers indicate elevation of water level [Colour figure can be viewed at wileyonlinelibrary.com]

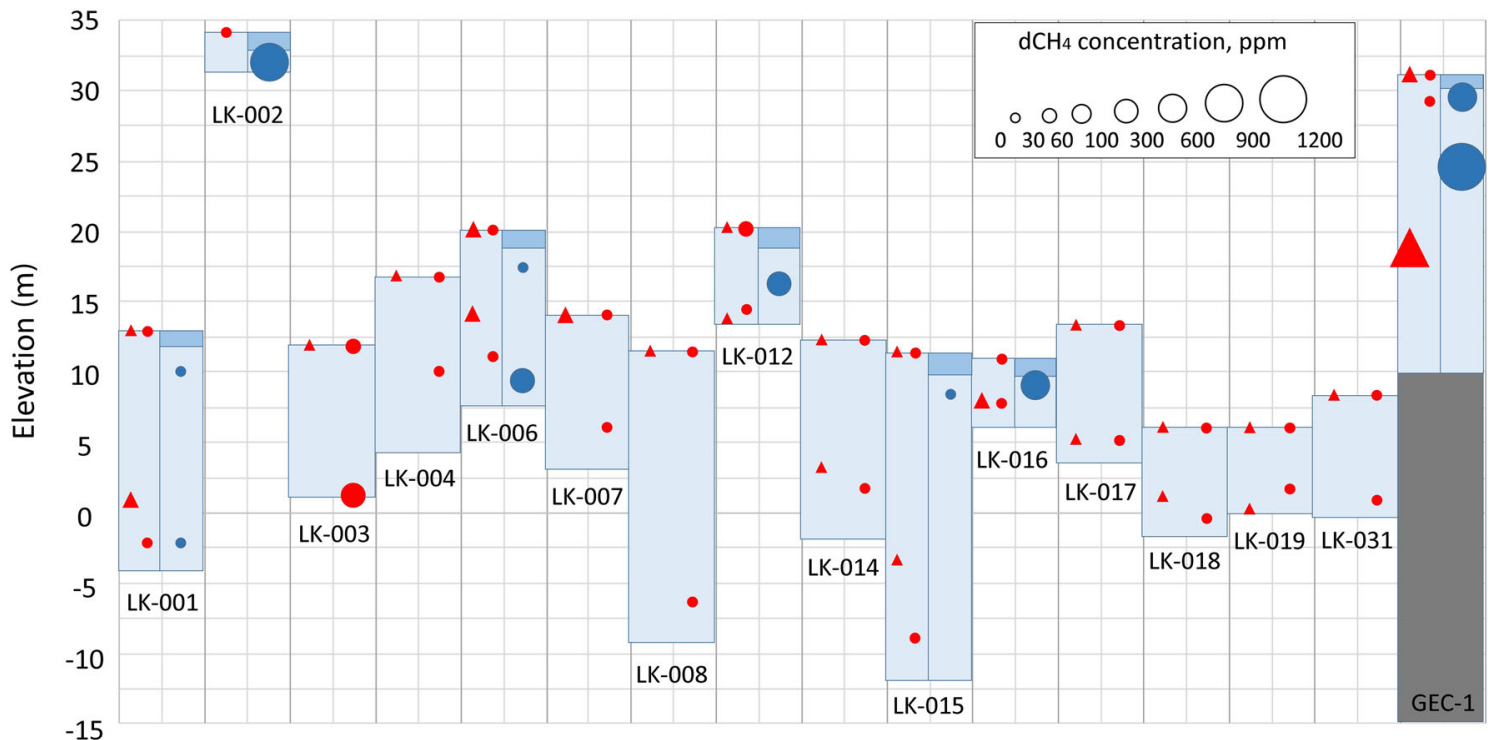

FIGURE 4 Distribution of $\mathrm{dCH}_{4}$ concentrations in water (blue rectangles) of Yamal lakes and GEC-1 lake. Red symbols indicate samples collected in summer (August-September), blue - early spring (April). Triangles - 2015 data, circles - 2017 data. Dark blue rectangles represent ice thickness in April. Gray shading indicates sediments filling GEC-1 in 2015 [Colour figure can be viewed at wileyonlinelibrary.com]

compared to summer 2015: DOC in 21 out of 23 lakes was $22 \%$ lower, varying in a range between 6 and 53.9\%. Two lakes (LK-017 and LK-031) were characterized by higher DOC in summer 2017 (by 9.9 and 20.5\%, respectively). A stronger seasonal difference was observed between April and August-September 2017. In April 2017,
DOC was on average $40.9 \%$ higher in six sampled lakes, with the difference varying between 17.1 and $87.3 \%$.

The estimated DOC concentration in AntGEC lake in 2016 was $8.8 \mathrm{mg} / \mathrm{L}$, while in five Gydan lakes DOC varied between 3.4 and $12.8 \mathrm{mg} / \mathrm{L}$ (7.3 $\mathrm{mg} / \mathrm{L}$ on average). 
TABLE 2 Concentration and isotopic composition of $\mathrm{dCH}_{4}$ collected from TGI, water of Yamal lakes and GEC-1 lake

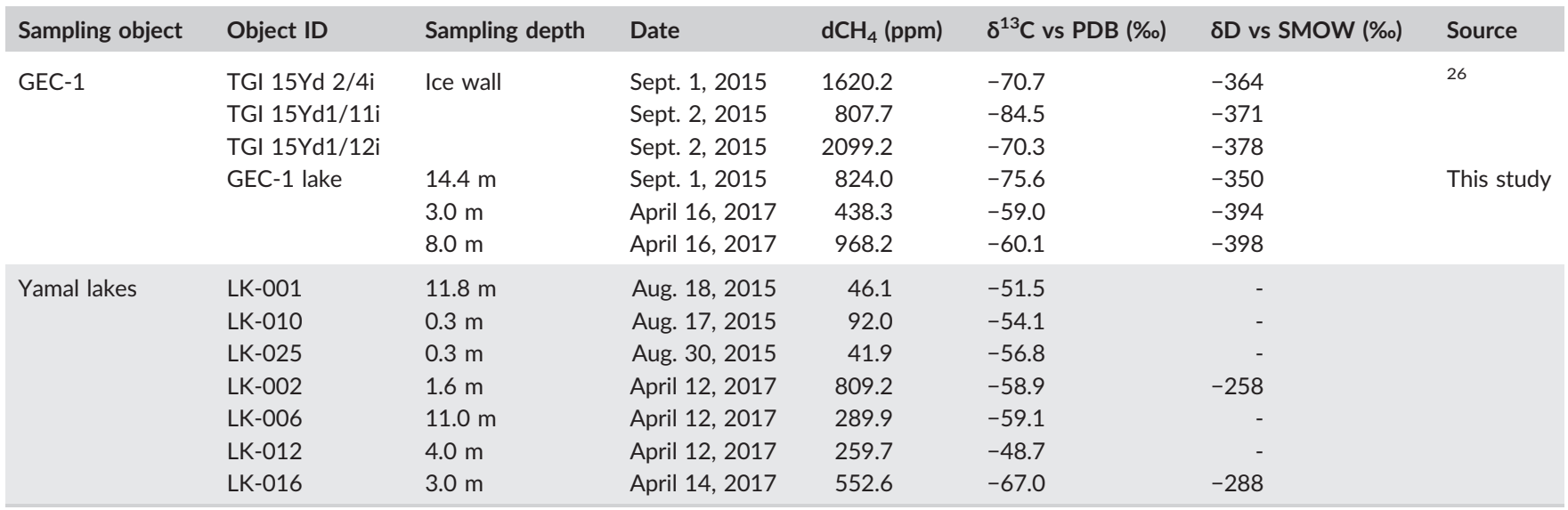

$\delta 180 \%$ vs VSMOW

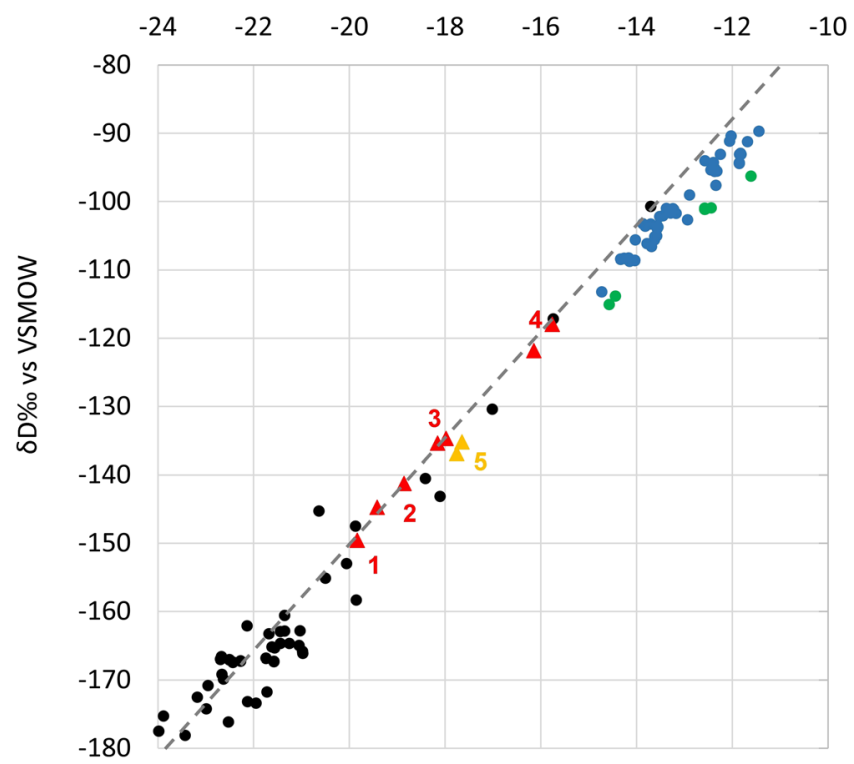

FIGURE 5 Stable isotopes $\left(\delta^{18} \mathrm{O}, \delta \mathrm{D}\right)$ of tabular ground ice (black dots, ${ }^{26}$ ), water from lakes (Yamal, blue dots; Gydan, green dots). Isotopes for water from GEC-1 are represented by red triangles with the following sampling dates: 1 - September $2014,{ }^{26} 2$ - September 2015, 3 - April 2017, 4 - September 2017. Samples from AntGEC are shown with yellow triangles, data from August 2016 (5) [Colour figure can be viewed at wileyonlinelibrary.com]

\subsection{4 | Major ions}

Given the marine origin of deposits in the area, major anions are dominated by $\mathrm{Cl}^{-}$(56.7 eq\% on average among all samples, $n=62$ ). The proportion of anions among all samples was in the order $\mathrm{Cl}$ ${ }^{-}>\mathrm{HCO}_{3}{ }^{-}>\mathrm{SO}_{4}{ }^{2-}$ except the Gydan lakes where the proportion of $\mathrm{SO}_{4}{ }^{2-}$ was higher than that of $\mathrm{HCO}_{3}{ }^{-}$.

Cations are strongly dominated by $\mathrm{Na}^{+}+\mathrm{K}^{+}$(58.5 eq\% on average among all samples, $n=62$ ). The proportion of cations was in the order
$\mathrm{Na}^{+}+\mathrm{K}^{+}>\mathrm{Mg}^{2+}>\mathrm{Ca}^{2+}$. The proportion of $\mathrm{HCO}_{3}{ }^{-}$in GEC-1 decreased through three sampling iterations: $74,55.7$ and 24 eq\% in samples taken in summer 2015, winter 2017 and summer 2017, being replaced by $\mathrm{Cl}^{-}$through time, the proportion of which consistently increased in a sequence 17.7, 35.4 and 59 eq\% respectively. During summer 2015 and 2017, the proportions of anions remained stable in Yamal lakes with an average of $56.7 \mathrm{eq} \% \mathrm{Cl}^{-}, 36.7 \mathrm{eq} \% \mathrm{HCO}_{3}{ }^{-}$and $5.4 \mathrm{eq} \%$ $\mathrm{SO}_{4}{ }^{2-}(2015, \mathrm{n}=24)$ and $53.2 \mathrm{eq} \% \mathrm{Cl}^{-}, 43.9$ eq\% $\mathrm{HCO}_{3}{ }^{-}$and 2.7 eq\% SO ${ }_{4}^{2-}(2017, n=25)$. The proportions of cations remained stable during summer 2015 and 2017, reflecting the general $\mathrm{Na}^{+}+\mathrm{K}$ ${ }^{+}>\mathrm{Mg}^{2+}>\mathrm{Ca}^{2+}$ scheme for the entire dataset. During winter 2017, Yamal lakes had higher proportions of $\mathrm{Cl}^{-}$(89.4 eq\%) among anions and $\mathrm{Na}^{+}+\mathrm{K}^{+}$(86.1 eq\%) among cations.

In 2016, the proportion of $\mathrm{Cl}^{-}$in AntGEC lake was higher (41 eq\%) compared with $\mathrm{HCO}_{3}{ }^{-}$(32.2 eq\%) and $\mathrm{SO}_{4}{ }^{2-}$ proportion (24.1 eq\%). The proportion of $\mathrm{HCO}_{3}{ }^{-}$was much higher than in other Gydan lakes (in only one lake out of five was the proportion higher than zero). Specifically for AntGEC lake and Gydan lakes the general scheme $\mathrm{Na}^{+}+\mathrm{K}$ ${ }^{+}>\mathrm{Mg}^{2+}>\mathrm{Ca}^{2+}$ remained undistinguishable.

\section{4 | Temperature profiles}

Water column temperature profiles were obtained in AntGEC and Gydan lakes in summer 2016 (Figure 6a), as well as in GEC-1 and Yamal lakes in April and summer 2017 (Figure 6b). Complete mixing of water masses was observed in summer in all Yamal and Gydan lakes, except for GEC lakes where some evidence of stratification was observed. In summer 2017, GEC-1 upper and bottom layers differed by $1.16^{\circ} \mathrm{C}\left(4.97^{\circ} \mathrm{C}\right.$ at $4.9 \mathrm{~m}$ and $6.13^{\circ} \mathrm{C}$ in the upper layer, measured on September 5, 2017).

In AntGEC, the upper and bottom layers differed by $1^{\circ} \mathrm{C}\left(8.8^{\circ} \mathrm{C}\right.$ in the upper layer and $7.8^{\circ} \mathrm{C}$ at $3.6 \mathrm{~m}$, measured on August 30,2016 ). The temperature difference in all lakes did not exceed $0.5^{\circ} \mathrm{C}$ between the upper layer and the bottom layer of the water column, including deep (>20 m) lakes (eg LK-015). Inverse stratification was observed 

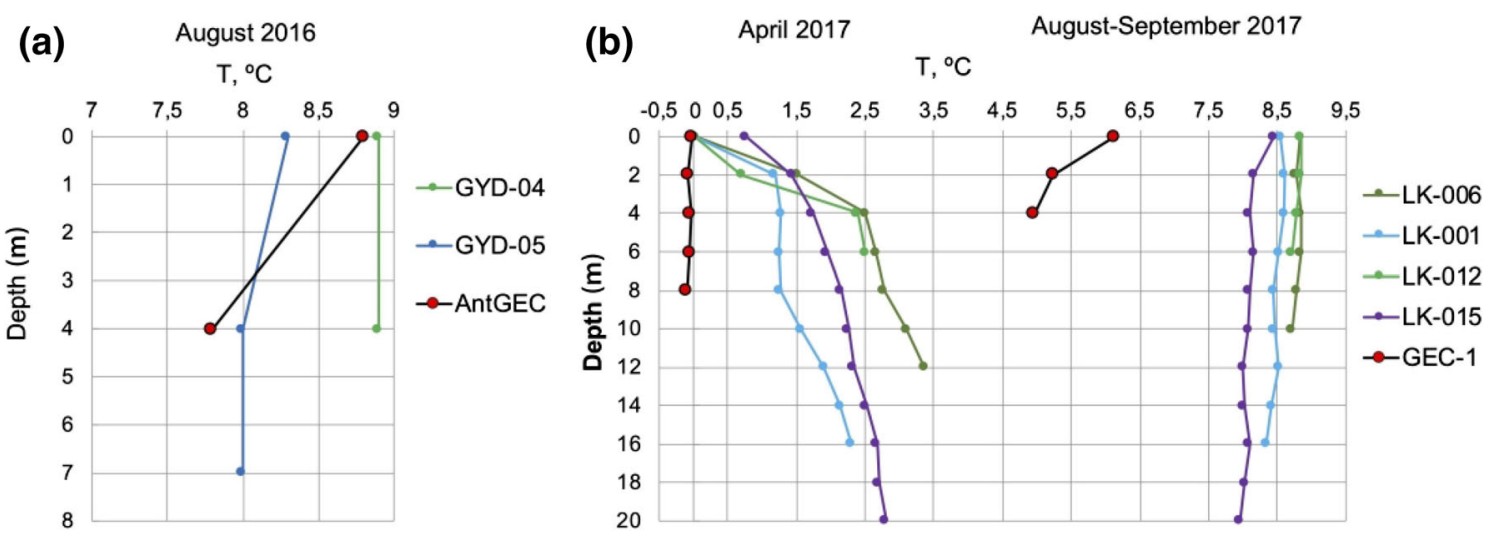

FIGURE 6 Temperature profiles recorded for AntGEC and two Gydan lakes (a) as well as for GEC-1 and Yamal lakes (b) [Colour figure can be viewed at wileyonlinelibrary.com]

in Yamal lakes in April 2017. The temperature of the upper layer in these lakes was close to zero $\left(0.02-0.77^{\circ} \mathrm{C}\right)$ while at the bottom water temperatures reached $3.36^{\circ} \mathrm{C}(\mathrm{LK}-006)$. At the same time, no stratification was observed in GEC-1 lake $\left(-0.02^{\circ} \mathrm{C}\right.$ in the upper layer and $-0.11^{\circ} \mathrm{C}$ at the bottom).

\section{4 | DISCUSSION}

\section{1 | Morphological features of newly formed GEC lakes}

In 2014, the initial depth of GEC-1 was more than $50 \mathrm{~m}^{9}$ and the depth of AntGEC was 15-19 m. ${ }^{8}$ After the appearance of GECs in October 2013, ${ }^{8}$ filling of the craters with rain water, melted snow, thawed ice and sediment from the retreating crater walls initiated the formation of new lakes. As a result of GEC-1 lake expansion, the parapet of GEC-19 was barely visible in 2016 , due to the processes of collapse and inundation. Similarly, the crater of AntGEC was barely recognizable. Therefore, we conclude that the GEC lakes transformed into a more common lake morphology over three consecutive summer seasons. This process is controlled by the topography of the area and lithology (ie sediment composition and texture) where the craters were formed. Our data show that GEC-1 decreased significantly in depth (maximum depth 23 m in September 2015 and 4.9 m in September 2017, Figure 2b,d). Despite the increase of GEC-1 lake area by 0.1 ha in two years, due to the retreating crater walls (22\% increase from the initial area in 2015) and despite additional drainage of lake LK-001_CR into GEC-1 lake (11,742 $\mathrm{m}^{3}$ of water), GEC-1 lake had a lower water volume in $2017\left(14,320 \mathrm{~m}^{3}\right)$ than in $2015\left(21,128 \mathrm{~m}^{3}\right)$ due to this significant filling of the crater with sediments.

In the case of AntGEC, which formed on the edge of a terrace, ${ }^{8,18}$ the newly formed hollow quickly filled with sediments (maximum depth of AntGEC lake in 2016 was only 3.6 m, Figure 2f), while the lower south-facing slope of AntGEC limited further accumulation of water. Therefore, AntGEC lake contained only $1643 \mathrm{~m}^{3}$ of water in 2016.

\section{2 | Hydrochemistry of GEC lakes}

\subsection{1 $\quad \mathrm{CH}_{4}$ source in GEC lakes}

GEC-1 lake was characterized by elevated $\mathrm{dCH}_{4}$ concentration in the bottom water layer in summer 2015 and early spring 2017 (824 and 968 ppm respectively). Values of $\mathrm{dCH}_{4}$ were 4-50 times higher than in Yamal lakes: 16 ppm on average based on the 2015 dataset and 241 ppm on average based on the early-spring 2017 dataset. We assume that methane release was active for at least two years after appearance of the crater.

Field observations in the Se-Yakha GEC area documented active gas bubbling within the newly formed water body that was filled with river water immediately after the gas emission event. ${ }^{27}$ However, in the GEC-1 lake, we did not observe any gas bubbles in 2015 or in 2017. Presumably, gas is continuously delivered from the gassaturated sediments under the lake and further oxidized in the water column. The extensive filling of the newly formed lakes with sediments from the retreating walls of GEC-1 and AntGEC ${ }^{8,9}$ implies that initial gas flows can be restrained by a thick and relatively impermeable layer of silty-clayey and sandy sediments. Given average ground temperatures around the GEC- 1 area of -1 to $-5^{\circ} \mathrm{C}^{28}$ we assume further freezing of sediments from below under the GEC-1 lake, probably forming a seal for further gas flows from beneath. On the other hand, we expect the development of a talik at the bottom of GEC lakes. Given a water temperature of GEC-1 lake close to $0^{\circ} \mathrm{C}$ (Figure $6 \mathrm{~b}$ ) and bottom temperature of $7.5-8^{\circ} \mathrm{C}$ in AntGEC lake (Figure 6a), we might expect faster talik development at the bottom of AntGEC lake. However, with the present data we cannot establish a modern boundary between frozen and thawed sediments under these two new lakes.

Our dataset on methane isotopes suggests that the source of methane is primarily microbial (Table 2), as the values of $\delta^{13} \mathrm{C}$ are, in general, less than $-60 \%{ }^{29}$ which is also consistent with the data presented by Buldovicz et al. ${ }^{16}$ Values of $\delta^{13} \mathrm{C}$ in methane extracted from deep boreholes of Bovanenkovo gas field (depths 28-120 m) vary from -74.6 to $-70.4 \%$, also suggesting a microbial origin. ${ }^{30}$ Similarly, methane released due to decomposition of methane hydrates 
extracted from a $451 \mathrm{~m}$ borehole in Taglu gas field (Canada) from depths of 56.9-354.3 $\mathrm{m}$ has shown $\delta^{13} \mathrm{C}$ values between -90 and $-78 \%$, and $\delta \mathrm{D}$ values between -314 and $-162 \%$, again suggesting microbial methane. ${ }^{31}$

Our data do not support the hypothesis that methane from deep sources was responsible for GEC-1 formation, as suggested in a number of publications. ${ }^{11,32,33}$ Continuous permafrost serves as an impermeable seal for the migration of gases from deep horizons, ${ }^{30,34-36}$ although it was also suggested that thermogenic methane can migrate to the upper horizons in Western Siberia. ${ }^{37}$ In a discontinuous permafrost area of the Mackenzie Delta, bubbles of thermogenic methane were documented on a lake surface. ${ }^{38}$ Moreover, gas bubbles persisted in lakes throughout the year, preventing formation of the lake ice in winter ( $\mathrm{K}$. Kohnert, pers. comm.). The concentration of $\mathrm{CH}_{4}$ in the gas phase of Yamal's TGl can reach up to 23,000 ppm. ${ }^{39,40}$ Therefore, methane dissolved in GEC-1 lake may in part originate from the gas phase of ice melted out of crater walls. However, the observed essential difference in $\mathrm{dCH}_{4}$ with depth in GEC-1 during summer 2015 and spring 2017 (Figure 4) supports the suggestion that methane seeps in the bottom sediments are connected to some initial methane source.

Records from deep boreholes in the area of Bovanenkovo gas field (42 km north of GEC-1) drilled in the 1990s have revealed a number of notable gas (87-99\% $\mathrm{CH}_{4}$ ) blowouts, with average flow rates of 500 $\mathrm{m}^{3} /$ day and reaching $14,000 \mathrm{~m}^{3} /$ day. $^{30,41}$ Blowouts mainly occurred at depths $60-120 \mathrm{~m}$ in silty sediments with $2-3 \mathrm{~cm}$ thick sand layers enriched with organic matter. ${ }^{34,42}$ Gas blowouts have been also observed to the south of the study area (Yuribey river, Southern Yamal) from depths less than $60 \mathrm{~m} .{ }^{43}$ Therefore, we conclude that microbial methane formed due to decomposition of gas hydrates was the most likely source of gas in GEC-1. ${ }^{9,14,44,45}$

\subsubsection{Water source in GEC lakes and lake water chemistry}

Lakes are natural reservoirs collecting material from surrounding catchments. ${ }^{46}$ Lake hydrochemistry reflects the geochemistry of the constituent bedrock and sediments of the lake catchment. Newly formed GECs are not an exception and these water bodies hold a geochemical signal of surrounding sediments. Furthermore, frozen crater walls contribute to the temperature regime of the water column.

The concentration of DOC in GEC lakes is controlled by the supply of allochtonous organic matter delivered from surrounding areas, ${ }^{47}$ peat layers and scattered organic matter in frozen deposits. A trend of increasing organic matter concentration within lake waters has been observed as a result of recent formation of thermocirques. ${ }^{48}$ The concentration of DOC in water extracted from peat layers of thermocirque exposures can reach $243 \mathrm{mg} / \mathrm{L} .{ }^{49}$

Based on two years of observations (see section 3.3.3), we found that the decreased rate of crater wall thawing and retreat as well as potential dilution by atmospheric precipitation has led to further DOC decline in GEC-1 lake. DOC concentrations in GEC-1 lake in 2017 were of similar magnitude $(9.2 \mathrm{mg} / \mathrm{L})$ as in other Yamal lakes
(3.7 mg/L). The abrupt decline in DOC in GEC-1 lake, from $50 \mathrm{mg} / \mathrm{L}$ in summer 2015 to $9.2 \mathrm{mg} / \mathrm{L}$ in summer 2017, significantly exceeded the seasonal and yearly DOC fluctuations in other Yamal lakes (Figure 7), and other West Siberian lakes. ${ }^{50}$

We observed the highest seasonal DOC concentrations in the shallow thermokarst lakes (eg LK-016), where DOC in April can be twice as high as in August. Larger, deep lakes such as LK-001 and LK-015 show more stable seasonal DOC fluctuations. In 2016, we found that DOC concentration in AntGEC lake $(8.8 \mathrm{mg} / \mathrm{L})$ was on the same order of magnitude as in Gydan lakes (7.3 mg/L), and therefore AntGEC lake is indistinguishable from other Gydan lakes. We found no evidence of peat inclusions in AntGEC remaining walls and we therefore assume the lower amount of allochtonous organic matter source available for AntGEC lake compared to GEC-1 lake.

The cryogeochemical model of the cryolithological section in central Yamal ${ }^{4,51}$ implies several horizons formed due to consistent epigenetic freezing of marine sediments in subaerial conditions after marine regression. The geological section comprises a layer of marine clays underlain by mostly sandy sediments containing highly mineralized liquid water (cryopegs) at different depths and TGI bodies at the claysand interface. ${ }^{51}$ The water chemistry of Yamal lakes is dominated by $\mathrm{Na}^{+}$and $\mathrm{Cl}^{-}$ions reflecting the marine origin of the sediments. The predominance of $\mathrm{HCO}_{3}{ }^{-}$in GEC-1 lake may be related to TGI. This has also been described by Olenchenko et al. ${ }^{14}$ Yamal TGI bodies with low mineralization $(<0.2 \mathrm{~g} / \mathrm{kg})$ may exhibit this dominance of $\mathrm{HCO}_{3}{ }^{-}$anions. ${ }^{52}$ This is caused by the genetic transformation of the initial seawater source into TGI. ${ }^{53}$

The proportion of $\mathrm{HCO}_{3}{ }^{-}$in TGI from the GEC-1 walls at different horizons exceeds $45 \mathrm{eq} \%$ at $18.6 \mathrm{~m}$ depth and can reach $81 \mathrm{eq} \%$ at $5.8 \mathrm{~m}$ depth. ${ }^{26}$ The dominance of $\mathrm{HCO}_{3}{ }^{-}$was also documented in other TGI bodies of Central Yamal. ${ }^{54}$ Total mineralization of water from GEC-1 (211.4 mg/L, 2015) and AntGEC (185 mg/L, 2016) lakes is close to the range of TGI mineralization from GEC-1 crater walls, with values ranging from 10 to $180 \mathrm{mg} / \mathrm{L}^{26} \mathrm{TG}$ found within the Se-Yakha and Mordy-Yakha river valleys had a similar mineralization

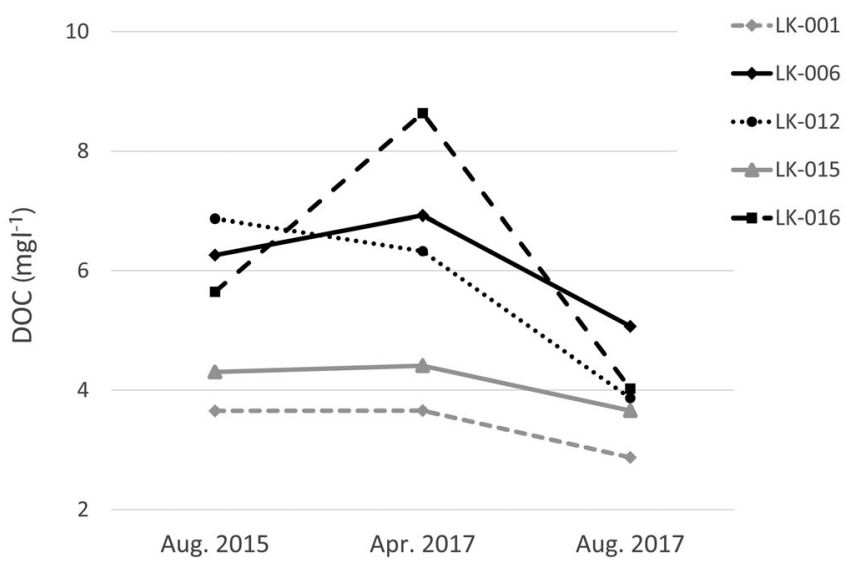

FIGURE 7 Seasonal dynamics of dissolved organic carbon (DOC) in Yamal lakes 
range of 26-176 mg/L $\mathrm{L}^{51}$ and TGI from Bovanenkovo gas field exposures exhibited a mineralization range of $9.7-168 \mathrm{mg} / \mathrm{L}^{54}$

Analysis of isotopes (Figure 5) also supports the hypothesis that thaw of TGI can provide a considerable source of the water in GEC-1 and AntGEC lakes. ${ }^{55}$ At the initial stage (2014), the isotopic composition of GEC-1 was closer to the isotopic composition of TGI found within GEC-1 and other exposures on the Yamal peninsula (Table 3). We therefore conclude that in the first stages of GEC formation the lake water source is dominated by thawed TGI. Later, atmospheric precipitation and runoff from a neighboring lake dilute the water, and the isotopic composition approaches -15 to $-11 \%$ o for $\delta^{18} \mathrm{O}$ and -115 to $-90 \%$ o for $\delta \mathrm{D}$ measured in Yamal and Gydan lakes (Figure 5, Table 3) as well as the average values of $\delta^{18} \mathrm{O}$ and $\delta \mathrm{D}$ for summer precipitation in the Yamal region $\left(-12.5\right.$ and $-96 \%$ o respectively, $\left.{ }^{54}\right)$.

The overall proportion of mineralized elements in GEC-1 lake does not differ significantly from the sampled subset of Yamal lakes (Figure 8a). On the other hand, the mineralization in AntGEC is one order of magnitude higher than in Gydan lakes and in lakes near Tazovskiy settlement (Figure 8b). The higher mineralization of Yamal lakes compared to Gydan lakes (with AntGEC as an exception) can be explained by the more complex topography and higher topographic gradient, potentially allowing more terrestrial material to be transported into lakes from catchments, ${ }^{48}$ as well as the presence of mineralized marine clays in the geological section. ${ }^{51}$ Notably, Yamal lakes with adjacent thermocirques (Figure 8a) have a higher concentration of all ions including $\mathrm{HCO}_{3}{ }^{-}$probably due to the input of melted water and sediments from retreating thermocirque walls. ${ }^{49,56}$

The seasonal hydrochemical dynamics of GEC-1 were different from other sampled Yamal lakes. The high concentrations of major ions in winter water samples implies the saturation of unfrozen water by salts, and isolation from atmospheric precipitation and terrestrial input. This results in an increase of $\mathrm{Na}^{+}$and $\mathrm{Cl}^{-}$ions, up to 90 eq\% on average. In the following summer, an increase in $\mathrm{HCO}_{3}{ }^{-}$can be observed in Yamal lakes, but this was not observed in GEC-1 lake: in summer 2017, the proportion of $\mathrm{HCO}_{3}{ }^{-}$in GEC1 lake had declined further. We link this to the decreased geochemical input from TGI in summer 2017 and lake water input from drained lake LK-001 CR. The total mineralization of GEC-1 lake has increased in summer 2017 (300 mg/L) compared to winter 2017 (190 mg/L). Therefore, in terms of hydrochemistry GEC-1 lake has transformed to a "normal lake."

TABLE 3 Isotopic composition of GEC lakes, Yamal and Gydan lakes, tabular ground ice from exposures found in Yamal, and atmospheric precipitation

\begin{tabular}{|c|c|c|c|}
\hline Object & $\delta^{18} \mathrm{O}(\%)$ & $\delta \mathrm{D}(\% \circ)$ & Reference \\
\hline GEC-1 (2014) & -19.8 & -149.6 & 26 \\
\hline GEC-1 (2017) & -16.1 to -15.8 & -122 to -118 & This study \\
\hline TGI (GEC-1 walls) & -20.6 & -152.4 & 26 \\
\hline TGI (Marre-Sale, west Yamal) & -18 to -17 & -160 to -130 & 26 \\
\hline TGI (se-Yakha, central Yamal) & -20.5 to -17.9 & -150.2 to -137.5 & 54 \\
\hline Yamal and Gydan lakes & -15 to -11 & -115 to -90 & This study \\
\hline Yamal (summer precipitation), average & -12.5 & -96 & 54 \\
\hline
\end{tabular}
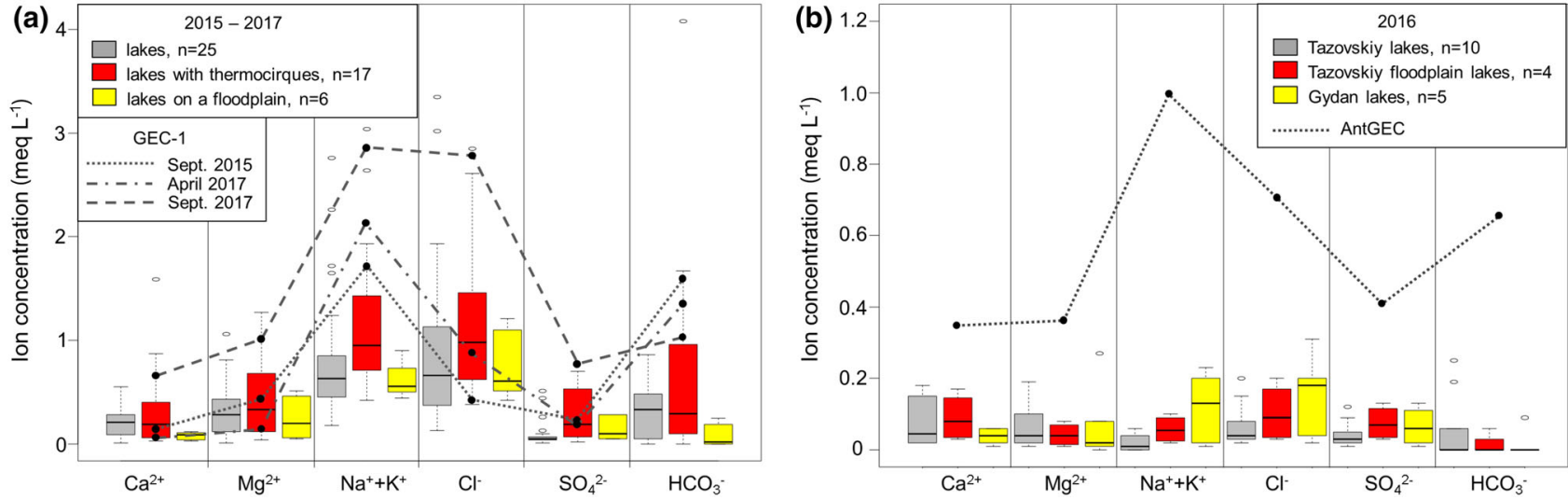

FIGURE 8 Concentration of ions in lake water: -(a) Yamal lakes and GEC-1 lake (2017 W and 2017 S in winter and summer); (b) Gydan and Tazovskiy lakes and AntGEC lake. Mineralization of Tazovskiy lakes - unpublished data. All lakes are divided into several groups: lakes with stable coasts, lakes with adjacent thermocirques, ${ }^{49}$ and floodplain lakes flooded in spring ${ }^{48}$ [Colour figure can be viewed at wileyonlinelibrary.com] 


\section{3 | Origin of crater-like depressions in the bottom of Yamal lakes}

In Western Siberia, crater-like depressions have been observed at the bottom of West Siberian lakes and termed gas-explosion craters. ${ }^{37,57}$ These craters were mapped in Yamal to identify degassing hot spots potentially related to deeper hydrocarbon formations. ${ }^{10,11,32,58} \mathrm{How}-$ ever, neither gas composition and concentration in these features nor morphometry were discussed in these publications. Kuzin et al. ${ }^{37}$ suggested that the occurrence of such features possibly results from gas advecting from deep sources (thermogenic $\mathrm{CH}_{4}$ ) and argue that they are often observed within oligotrophic "blue lakes" characterized by low $\mathrm{pH}$, and lack of phyto- and zooplankton.

However, we have observed such crater-like depressions in Yamal lakes that cannot be considered as "blue lakes." These features are not visible on satellite images or from a helicopter given the considerable water depth and sometimes high turbidity. ${ }^{59}$ Detailed bathymetric surveys in 22 lakes revealed several depressions (Table 1) having either a circular or elongated shape close to lake shores with different morphology: from absolutely flat terrain (eg LK-003) to high cliffs (eg LK-012). Such depressions are 10-20 m deep relative to the bottom of the lakes, and have steep slopes $\left(>36^{\circ}, 8.1^{\circ}\right.$ on average). For Yamal lakes, crater-like depressions have also been linked to thaw of TGI and are often associated with elevated shores. ${ }^{21}$ Similarly, in the Canadian Arctic, lake-bottom depressions were reported as being connected closely to shores with active or stable retrogressive thaw slumps. ${ }^{60}$ Water depths on these shores were on average $4 \mathrm{~m}$ greater than stable undisturbed shores. Therefore, these depressions were associated with lake bottom subsidence due to enlargement of taliks under lakes caused by ground temperature increases. ${ }^{60}$ Given that the base of TGI on Yamal may be located as low as $21.2 \mathrm{~m}$ b.s.l. in Yamal $^{3}$ and the minimum elevation of all mapped depressions reached only $12 \mathrm{~m}$ b.s.l., it is possible that depressions have been formed as a result of TGI degradation. ${ }^{21,60}$ Alternatively, depressions could result from microbial gas flows or blowouts from permafrost, contrary to deeper source migration, previously suggested by Kuzin, ${ }^{37}$ and Bogoyavlenskiy et al. ${ }^{33}$ Low $\mathrm{dCH}_{4}$ concentrations measured in the water sampled in crater-like depressions (20-60 ppm, Figure 4) can be explained by depletion of gas storages. This was probably the case for GEC-1: in summer 2017 the $\mathrm{dCH}_{4}$ concentration was only 23 ppm (Figure 4).

Similar forms (pockmarks) have been previously observed in submarine environments around the world where they are related to the release of free gas from the seafloor into the water column. ${ }^{61}$ Submarine pockmarks vary significantly in shape and size, with depths from $1 \mathrm{~m}$ to several tens of meters, diameters reaching hundreds of meters and slopes as steep as $30^{\circ}$.

An alternative hypothesis for the formation of depressions implies former river/stream valleys, as these depressions are sometimes elongated and connected to lake inlets or outlets. Several channel-like depressions have been mapped on the bottom of Yamal lakes (eg LK-018, LK-031). Retrieval of deep sediment cores from local sub-lake depressions is required to further clarify their origin.
With the present data we cannot establish an exact origin of all mapped depressions. Multiple origins of crater-like depressions reported in the literature are plausible.

\section{4 | Mechanisms of GEC formation and future landscape evolution}

Crater-like depressions were first observed in the marine environment on the Nova Scotian Shelf (North Sea) in the late 1960s, and these were named pockmarks. ${ }^{62}$ Further studies led to detailed characterization of such structures in submarine conditions ${ }^{63}$ and concluded that pockmarks are formed due to gas release from the seafloor and therefore present a significant methane source. ${ }^{61}$ Despite the fact that both West Siberian craters and submarine pockmarks are conditioned by the process of gas release, theories regarding their mechanisms of formation differ. Pockmarks generated in submarine conditions form as a result of consistent gas release, which disturbs soft bottom sediments on centennial to millennial timescales. In contrast, craters on Yamal were generated extremely rapidly in subaerial conditions, due to short and rapid episodes of permafrost-bounded gas outburst.

The closest offshore analogs of the modern GECs can be found on the South Kara Sea shelf, where hundreds of buried ancient thermokarst structures have been recently mapped based on seismic data. ${ }^{64}$ These subsea structures reach tens of meters in depth and are acoustically transparent, probably due to the collapsed, unconsolidated sediments infilling them, which is in good agreement with the observations from Yamal and Gydan craters.

Kizyakov et al. ${ }^{12}$ showed that before the GEC-1 appeared, a 5-6 m high and 45-58 $\mathrm{m}$ wide mound existed at that location. Similarly, a $2 \mathrm{~m}$ high and $20 \mathrm{~m}$ wide mound preceded the emergence of AntGEC on the Gydan peninsula. ${ }^{8}$ Similar mounds were previously described in the submarine environment as pingo-like features (PLFs): in the Beaufort Sea, ${ }^{65}$ and Barents-Kara Sea shelves 5-9 $\mathrm{m}$ in height and 70-1000 $\mathrm{m}$ in diameter, ${ }^{36,66}$ and on the Pechora Sea shelf showing base diameters from 20 to $1000 \mathrm{~m}$ and heights of 5-25 m. The drilling of one of these PLFs in the Pechora Sea led to the blowout of a large amount of gas from a depth of $49.5 \mathrm{~m}$ and failure of the drilling equipment. $^{67}$ The concentration of microbial methane in sediments collected from the flank of a PLF in the Kara Sea exceeded 120,000 ppm. ${ }^{66}$ The source of the gas that creates overpressure in the PLFs is either decomposition of methane hydrates, ${ }^{65}$ or gases accumulated within lenses of thawed sands located below the base of submarine permafrost. ${ }^{67}$ Gas-bearing sediments have also been revealed in the South Kara Sea shelf at the clay-sand interface. ${ }^{68,69}$ There are at least two main hypotheses for the origin of PLFs: (a) they formed under subaerial conditions during the Pleistocene and are analogs of terrestrial pingoes (bulgunnyakhs), and then became inundated during Holocene transgression; and (b) they were formed in submarine conditions ( ${ }^{36}$ and references therein). Given the start of formation of the GEC-1 mound-predecessor in the Here the right reference is 17 (Arefyev et al. 2017)1940s, ${ }^{17}$ it is rather a modern process. 
Based on the results of GEC studies and related submarine analogs, we propose a conceptual model for GEC formation and evolution. This model may also help to determine potential scenarios of future landscape development in permafrost regions (Figure 9). In the terrestrial and nearshore environment, methane originates from shallow intrapermafrost gas occurrences or relic gas hydrate reservoirs ${ }^{43}$ within the relic gas hydrate distribution zone deeper than
$70 \mathrm{~m}$ b.s.l. in the continuous permafrost. This gas might further migrate and accumulate within a cryotic layer of saline sediments that can often be observed at 25-35 m b.s.I. on Yamal. ${ }^{51}$ This is also supported by documented gas blowouts from depths of $70-120 \mathrm{~m}^{30}$ during drilling of boreholes in Central Yamal, mainly from sandy coastalmarine deposits. ${ }^{70}$ Gas flows can create pressure in areas with the development of $\mathrm{TGI}$ at the clay-sand interface, ${ }^{51}$ which results in
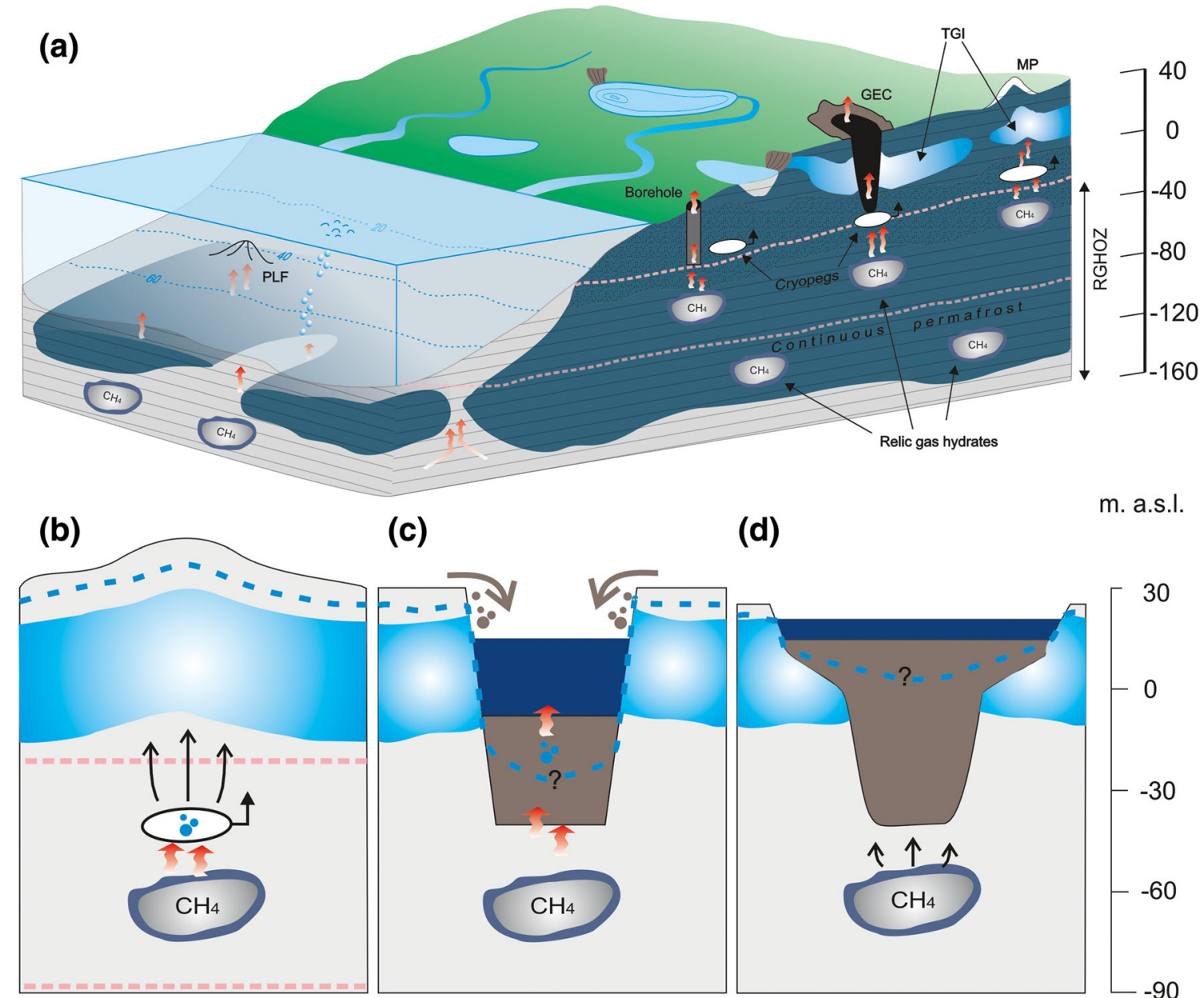

(c)

(d)

m. a.s.l.
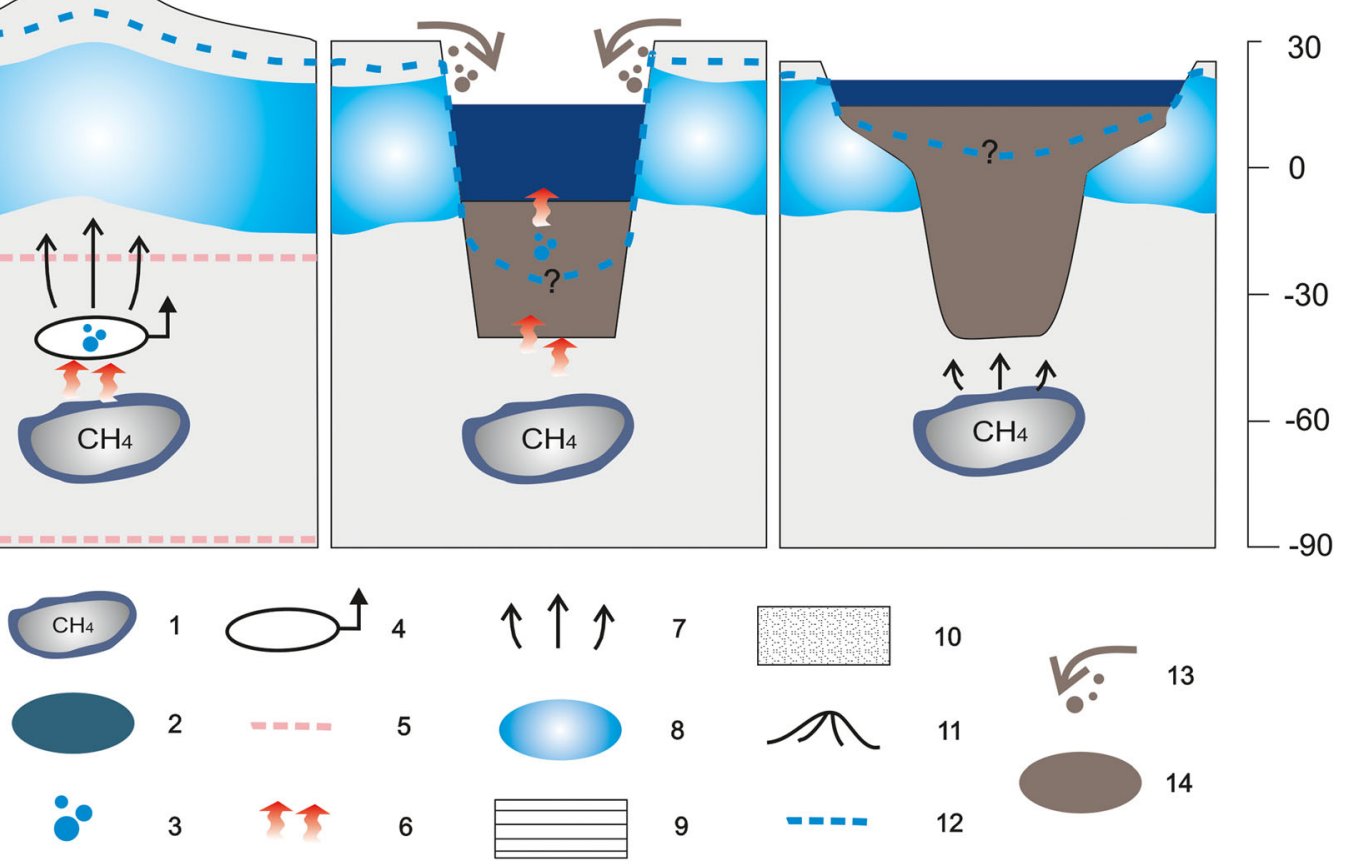

FIGURE 9 Possible gas escape mechanisms in the terrestrial and nearshore environment originating from decomposed gas hydrates (a) and stages of GEC-1 formation (b,c,d). Relic gas hydrate reservoirs $\left(1,{ }^{43}\right)$ within the relic gas hydrate occurrence zone (RGHOZ) stored in the continuous permafrost (2) can be a potential free gas (3) source that can be stored within unfrozen cryopegs (4) widely distributed at depths of 25-35 m b.s.l. on the Yamal peninsula. ${ }^{51}$ This is supported by documented gas blowouts mainly from depths of $70-120 \mathrm{~m}\left(5,{ }^{30}\right)$ during drilling of boreholes (BH) in central Yamal. Gas flows (6) can create a pressure (7) in areas with tabular ground ice (TGI) occurrence (8) at the clay (9) - sand (10) interface, ${ }^{51}$ which results in the development of a mound-predecessor (MP) on the ground surface (b) and pingo-like features (PLFs) (11) documented analogs in the nearshore environment. ${ }^{36,66}$ An inncrease in active layer thickness (12) may lead to the formation of gas-emission craters (GECs) $\left(c,{ }^{9}\right)$ which are then filled (13) with sediments from crater walls (14). These new layers of sediments $>50 \mathrm{~m}$ then re-freeze (d) preventing further gas escapes from permafrost. The base of permafrost is derived from, ${ }^{14}$ geological section for central Yamal is modified after. ${ }^{51}$ GEC characteristics are taken from. ${ }^{9}$ Elevation is given in meters above and below sea level in a Baltic system [Colour figure can be viewed at wileyonlinelibrary.com] 
the development of a mound-predecessor in the terrestrial environment (Figure 9b) and PLFs in the nearshore environment. ${ }^{36,66}$

An abnormally warm summer in the Arctic in 2012 increased the active layer thickness in the Yamal peninsula. ${ }^{71}$ This weakened the upper frozen layer which we infer would have contributed to GEC formation. ${ }^{9}$ The GEC was further infilled with collapsed sediments from the crater walls (Figure 9c). This new $>50 \mathrm{~m}$ thick sediment layer is likely to refreeze from below, preventing further gas release from permafrost (Figure 9d).

\section{5 | CONCLUSIONS}

The data collected from the GEC-1 and AntGEC sites as well as from Yamal and Gydan lakes showed that many lakes in the West Siberian Arctic may have origins that are potentially similar to GECs: a hollow formed as a result of intensive gas emission. This process can also be involved in shaping the lake basins, as residual gas emission at the lake bottom is common even after the major episode of gas outburst.

1. GEC lakes transformed into lakes over three consecutive summer seasons. This process is controlled by the topography and lithology of the area where the craters were formed.

2. Yamal lakes are characterized by local (1-18\% of the lake area) crater-like depressions on their bottom (more than $50 \%$ of measured lakes). These depressions have an average slope of $8.1^{\circ}$ (reaching $36^{\circ}$ ). Our data do not show whether these crater-like depressions originate from gas emission or from the thaw of tabular ground ice. Moreover, these depressions can be interpreted as paleo-stream valleys. Retrieving lake sediment cores is required to clarify the origin of each depression.

Hydrochemical analyses of GEC lakes also suggests that three years can be enough for the GEC water column to become indistinguishable from other lakes. Our monitoring data suggest that the dynamics of several hydrochemical parameters in GEC lakes differ from the seasonal and yearly dynamics of these parameters in other lakes.

3. At the first stage of new lake formation, a high dissolved methane concentration of microbial origin characterizes the water column, especially bottom layers.

4. A higher concentration of methane in the bottom layer indicates that the source of methane is from beneath the TGI rather than from the frozen deposits of the crater walls and TGI itself, although it is characterized by a high methane concentration as well.

5. The isotopic composition of the water as well as major ions of GEC-1 lake water suggest that thawed TGI is a dominant water source at the first stage of GEC formation. The isotopic composition of GEC lake water is quite close to the specific composition of TGI. The water of GEC lakes was also characterized by a higher proportion of $\mathrm{HCO}_{3}{ }^{-}$anions, which is also a common signature of $\mathrm{TGI}$. We observed a gradual increase in the proportion of atmospheric precipitation in GEC-1 lake from 2014 to 2017.

6. Yamal lakes are characterized by higher DOC in winter compared to the end of summer. In GEC-1, however, we observed a gradual DOC decline from 2015, reaching a similar level as in other lakes, which suggesting the stabilization of constant organic matter input from retreating crater walls and dilution by atmospheric precipitation. In turn, the concentration of major ions is increasing in GEC-1 lake, becoming closer to that in Yamal lakes. The concentration of major ions in AntGEC lake water was one order of magnitude higher than in Gydan and Tazovskiy lakes.

7. Known ground temperature for the GEC-1 area and measured temperature regime of GEC-1 and AntGEC lakes suggest that, at least in GEC-1, a thick layer of modern sediments filling its hollow (>50 $\mathrm{m}$ ) has undergone further re-freezing from below. In summer 2017, the bottom temperature of GEC-1 lake was two-fold lower than in Yamal lakes due to the surrounding frozen walls. This may slow down the development of the talik, at least under GEC-1 lake. Further geophysical studies are required to define the thickness of unfrozen sediments. The refreezing of sediments from below can potentially prevent further gas seepage into the water column, resulting in a decrease in dissolved methane concentration in the water of new lakes, as has already been observed in GEC-1 lake (summer 2017 data). AntGEC walls covered by sandy talus prevent direct contact between lake water and frozen deposits, and thus the lake's water column exhibits a higher overall temperature. This can potentially lead to faster talik development and to thinning of the lower layer that is impermeable to escaping gas.

We analyzed diverse datasets from this permafrost region in order to explain the mechanism of GEC formation. In the terrestrial and nearshore environment, methane originates from intra-permafrost gas accumulations or relic gas hydrate reservoirs within the relic gas hydrate distribution zone deeper than $70 \mathrm{~m}$ b.s.l. in the continuous permafrost. This gas further migrated and accumulated within a layer of cryotic saline deposits that are often observed at 25-35 m b.s.l. on the Yamal peninsula. The accumulated methane created pressure in areas with TGI at the clay-sand interface, which resulted in the development of a mound-predecessor. As pressure within this mound-predecessor exceeded the confining strength of the overlying substrate, a GEC erupted.

\section{ACKNOWLEDGEMENTS}

This work was supported by Russian Science Foundation (RSF) grant No. 16-17-10203 and partially supported by Russian Foundation for Basic Research (RFBR) grants No. 18-05-60080 and 18-05-60222. We thank Otto Schmidt Laboratory for Polar and Marine Research (OSL) for providing laboratory facilities. We also thank two anonymous reviewers and the editor for valuable comments and improvements to the manuscript. 


\section{ORCID}

Yury A. Dvornikov (D) https://orcid.org/0000-0003-3491-4487

Marina O. Leibman (D) https://orcid.org/0000-0003-4634-6413

Artem V. Khomutov (D) https://orcid.org/0000-0001-8855-3483

Alexander I. Kizyakov (D) https://orcid.org/0000-0003-4912-1850

Ingeborg Bussmann (D) https://orcid.org/0000-0002-1197-7461

Birgit Heim (D) https://orcid.org/0000-0003-2614-9391

Alexey Portnov (1) https://orcid.org/0000-0003-4930-8308

Irina D. Streletskaya (D) https://orcid.org/0000-0001-5645-8772

Anna Kozachek (1) https://orcid.org/0000-0002-9704-8064

Hanno Meyer (1D https://orcid.org/0000-0003-4129-4706

\section{REFERENCES}

1. Baulin VV, Chekhovskiy AL, Sukhodolskiy SE. Main stages of permafrost development in the North-East of Western part of USSR and Western Siberia. In: Dubikov GI, Baulin VV, eds. History of Development of Permafrost in Eurasia: On the Examples of Separate Regions. Moscow, Russia: Nauka; 1981:41-60.

2. Yunak RI. Permafrost in the Yamal-Gydan area of Western Siberia. Polar Geogr. 1979;3(1):49-63. https://doi.org/10.1080/ 10889377909377101

3. Dubikov Gl. Paragenesis of massive ground ice and frozen rocks of Western Siberia. In: Massive Ground Ice of the Permafrost Zone. Yakutsk, Russia: MPI SB RAS; 1982:24-42.

4. Streletskaya ID, Leibman MO. Cryogeochemical model of tabular ground ice and cryopegs, Yamal peninsula, Russia. In: Phillips, Springman, Arenson, eds. 8th International Conference on Permafrost. Zurich, Switzerland: Swets \& Zeitlinger; 2003:1111-1116.

5. IPCC. Climate change 2014: synthesis report. Geneva, Switzerland: IPCC; 2014.

6. Romanovsky VE, Drozdov DS, Oberman NG, et al. Thermal state of permafrost in Russia. Permafr Periglac Process. 2010;21(2):136-155. https://doi.org/10.1002/ppp.683

7. Leibman MO, Plekhanov AV. The Yamal gas emission crater: results of preliminary survey. KholodOK 2014:9-15.

8. Kizyakov Al, Zimin MV, Sonyushkin AV, Dvornikov YA, Khomutov AV, Leibman MO. Comparison of gas emission crater geomorphodynamics on Yamal and Gydan peninsulas (Russia), based on repeat very-highresolution stereopairs. Remote Sens (Basel). 2017;9(10). https://doi. org/10.3390/rs9101023

9. Leibman MO, Kizyakov Al, Plekhanov AV, Streletskaya ID. New permafrost feature - deep crater in central Yamal (West Siberia, Russia) as a response to local climate fluctuations. Geogr Environ Sustain. 2014;7(4):68-79. https://doi.org/10.24057/2071-9388-2014-7-4-6879

10. Bogoyavlenskiy VI. Threat of catastrophic gas blowouts from the Arctic permafrost zone. Yamal and Taimyr craters, part 2. Oil Drill. 2014;10:4-9.

11. Bogoyavlenskiy VI. Threat of catastrophic gas blowouts from the Arctic permafrost zone. Yamal and Taimyr craters, part 1. Oil Drill. 2014;9:13-18

12. Kizyakov Al, Sonyushkin AV, Leibman MO, Zimin MV, Khomutov AV. Geomorphological conditions of the gas-emission crater and its dynamics in central Yamal. Earth's Cryosph. 2015;19(2):13-22.

13. Kojina LY, Miklyaeva ES, Perlova EV, Sinitskiy Al, Tkacheva EV, Cherkasov VA. Dangerous contemporary phenomenons of cryoactivity-the main results of the Yamal crater study. Sci Bull Yamalo Nenets Auton Dist. 2015;2:19-28.
14. Olenchenko VV, Sinitskiy Al, Antonov EY, et al. Results of geophysical surveys of the area of Yamal crater, the new geological structure. Earth Cryosph. 2015;19(4):84-95. http://www.izdatgeo.ru

15. Leibman MO, Dvornikov YA, Khomutov AV, et al. Hydro-chemical features of water in lakes and gas-emission craters embedded in the marine deposits of West-Siberian North. In: Lisitsyn AP, Politova NV, Shevchenko VP, eds. Geology of Seas and Oceans: Proc. of XXII International Conference on Marine Geology. Moscow, Russia: IO RAS; 2017:117-120.

16. Buldovicz SN, Khilimonyuk VZ, Bychkov AY, et al. Cryovolcanism on the earth: origin of a spectacular crater in the Yamal peninsula (Russia). Sci Rep. 2018;8(1):13534. https://doi.org/10.1038/s41598-01831858-9

17. Kizyakov Al, Khomutov AV, Zimin MV, et al. Microrelief associated with gas emission craters: remote-sensing and field-based study. Remote Sens (Basel). 2018;10(5). https://doi.org/10.3390/ rs10050677

18. Kizyakov Al, Sonyushkin AV, Khomutov AV, Dvornikov YA, Leibman MO. Assessment of the relief-forming effect of the Antipayuta gas emission crater formation using satellite stereo pairs. Sovrem Probl Distantsionnogo Zo Zemli iz Kosmosa. 2017;14(4):67-75. https://doi. org/10.21046/2070-7401-2017-14-4-67-75

19. Arefyev SP, Khomutov AV, Ermokhina KA, Leibman MO. Dendrochronologic reconstruction of gas-inflated mound formation at the Yamal crater location. Earth Cryosph. 2017;21(5):107-119. https://doi.org/10.21782/KZ1560-7496-2017-5(107-119)

20. Moscow State University. In: Trofimov VT, ed. The Yamal Peninsula. Moscow, Russia: MSU; 1975.

21. Romanenko FA. Dynamic of lake basins. In: Sidorchuk AY, Baranov AV, eds. Processes of Erosion on Central Yamal. Saint-Petersburg, Russia: Gomel CNTDI; 1999:139-160.

22. Artic and Antarctic Research Institute. In: Sisko RK, ed. Yamal-Gydan Area. Saint-Petersburg, Russia: Gidrometeoizdat; 1977.

23. Dvornikov YA, Leibman MO, Heim B, et al. Geodatabase and WebGIS project for long-term permafrost monitoring at the Vaskiny Dachi Research Station, Yamal, Russia. Polarforschung. 2016;85(2):107-115. https://doi.org/10.2312/polfor.2016.007

24. Magen C, Lapham LL, Pohlman JW, et al. A simple headspace equilibration method for measuring dissolved methane. Limnol Oceanogr Methods. 2014;12(9):637-650. https://doi.org/10.4319/ lom.2014.12.637

25. Taipale SJ, Sonninen E. The influence of preservation method and time on the $13 \mathrm{C}$ value of dissolved inorganic carbon in water samples. Rapid Commun Mass Spectrom. 2009;23(16):2507-2510. https://doi.org/ $10.1002 / \mathrm{rcm} .4072$

26. Streletskaya ID, Leibman MO, Kizyakov Al, Oblogov GE, Vasiliev AA, Khomutov AV, Dvornikov YA. Ground ice and its role in the formation of gas-emission crater in the Yamal peninsula. Moscow Univ Bull Ser 5 , Geogr. 2017;2:91-99.

27. TV and Radio Company Yamal-Region. New Yamal crater, Photofact. http://yamal-region.tv/news/26092. Published 2018. Accessed April 4, 2018.

28. Khilimonyuk VZ, Ospennikov EN, Buldovicz SN, Gunar AY, Gorshkov El. Geocryological conditions of Yamal crater location. In: 5th Conference of Russian Geocryologists. Moscow, Russia: University Book; 2016:245-255.

29. Bernard BB, Brooks JM, Sackett WM. Natural gas seepage in the Gulf of Mexico. Earth Planet Sci Lett. 1976;31(1):48-54. https://doi.org/ 10.1016/0012-821X(76)90095-9 
30. Skorobogatov VA, Yakushev VS, Chuvilin EM. Sources of natural gas within permafrost (North-West Siberia). In: 7th International Conference on Permafrost. Yellowknife, Alaska: Collection Nordicana; 1998:1001-1007.

31. Dallimore SR, Collett TS. Intrapermafrost gas hydrates from a deep core hole in the Mackenzie Delta, Northwest Territories, Canada. Geology. 1995;23(6):527-530. https://doi.org/10.1130/00917613(1995)023<0527:IGHFAD>2.3.CO;2

32. Sizov OS. Remote sensing data analysis of the consequences of gas releases in the north of Western Siberia. Geomatica. 2015;1:53-68.

33. Bogoyavlenskiy VI, Bogoyavlenskiy IV, Nikonov RA. Results of aerial, space and field investigations of large gas blowouts near Bovanenkovo field on Yamal peninsula. Arct Ecol Econ. 2017;3(27):4-17. https://doi. org/10.25283/2223-4594-2017-3-4-17

34. Rivkina EM, Kraev GN, Krivushin KV, et al. Methane in permafrost of northeastern Arctic. Earth Cryosph. 2006;10(3):23-41.

35. Shakhova N, Semiletov I, Salyuk A, Yusupov V, Kosmach D, Gustafsson Ö. Extensive methane venting to the atmosphere from sediments of the east Siberian Arctic shelf. Science. 2010;327(5970):1246-1250. https://doi.org/10.1126/science.1182221

36. Portnov A, Smith AJ, Mienert J, et al. Offshore permafrost decay and massive seabed methane escape in water depths $>20 \mathrm{~m}$ at the South Kara Sea shelf. Geophys Res Lett. 2013;40(15):3962-3967. https:// doi.org/10.1002/grl.50735

37. Kuzin IL. On the priority in the study of surface gas emissions in Western Siberia. Geol Geophys. 1990;3:142-144.

38. Kohnert K, Serafimovich A, Metzger S, Hartmann J, Sachs T. Strong geologic methane emissions from discontinuous terrestrial permafrost in the Mackenzie Delta, Canada. Sci Rep. 2017;7(1):5828. https://doi. org/10.1038/s41598-017-05783-2

39. Vasiliev AA, Streletskaya ID, Melnikov VP, Oblogov GE. Methane in ground ice and frozen quaternary deposits of Western Yamal. Dokl Earth Sci. 2015;465(2):1289-1292. https://doi.org/10.1134/ S1028334X15120168

40. Streletskaya ID, Vasiliev AA, Oblogov GE, Semenov PB, Vanshtein BG, Rivkina EM. Methane in ground ice and frozen sediments in the coastal zone and on the shelf of Kara Sea. Ice Snow. 2018;58(1):65-77. https:// doi.org/10.15356/2076-6734-2018-1-65-77

41. Chuvilin EM, Yakushev VS, Perlova EV. Gas and possible gas hydrates in the permafrost of bovanenkovo gas field, Yamal peninsula, West Siberia. Polarforschung. 2000;68:215-219.

42. Rivkina EM, Gilichinskiy DA. Methane as a palaeoindicator of the origin and dynamics of permafrost. Lithol Miner Resour. 1996;4:183-193.

43. Yakushev VS. Natural Gas and Gas Hydrates in Cryolithozone. Moscow, Russia: VNIIGAZ; 2009.

44. Khimenkov AN, Sergeev DO, Stanilovskaya JV, Vlasov AN, VolkovBogorodskiy DB. Gas emissions in the cryolithozone: a new type of geocryological hazards. Georisk. 2017;3:58-65.

45. Khimenkov AN, Stanilovskaya JV, Sergeev DO, et al. Development of explosion processes in criolithozone with a link to Yamal crater. Arct Antarct. 2018;4:13-37.

46. Wetzel RG. Limnology: Lake and River Ecosystems. San-Diego, California: Academic Press; 2001.

47. Wauthy M, Rautio M, Christoffersen KS, et al. Increasing dominance of terrigenous organic matter in circumpolar freshwaters due to permafrost thaw. Limnol Oceanogr Lett. 2018;3(3):186-198. https://doi.org/ 10.1002/lol2.10063

48. Dvornikov YA, Leibman MO, Heim B, et al. Terrestrial CDOM in lakes of Yamal peninsula: connection to lake and lake catchment properties.
Remote Sens (Basel). 2018;10(2):167. https://doi.org/10.3390/ rs10020167

49. Dvornikov YA, Leibman MO, Heim B, Khomutov AV, Rößler S, Gubarkov AA. Thermodenudation on Yamal peninsula as a source of the dissolved organic matter increase in thaw lakes. Earth Cryosph. 2017;21(2):33-42. https://doi.org/10.21782/KZ1560-7496-20172(33-42)

50. Manasypov RM, Vorobyev SN, Loiko SV, et al. Seasonal dynamics of organic carbon and metals in thermokarst lakes from the discontinuous permafrost zone of western Siberia. Biogeosciences. 2015;12(10):3009-3028. https://doi.org/10.5194/bg-12-3009-2015

51. Streletskaya ID, Leibman MO. Cryogeochemical interrelation of massive ground ice, cryopegs and enclosing deposits of central Yamal. Earth Cryosph. 2002;6(3):15-24.

52. Fotiev SM. The regularities in the formation of natural waters of ionicsalt composition, Yamal peninsula. Earth' Cryosph. 1999;3(2):40-65.

53. Koreysha MM, Khimenkov AN, Bryksina GS. The occurrence and the structure of massive tabular ground ice in the visinity of the lake Ney-To region (Yamal peninsula). In: Regional and Engineering Geocryology Issues. Moscow, Russia: Stroyizdat; 1983:73-88.

54. Vasil'chuk YK, Budantseva NA, Vasil'chuk DY, Vasil'chuk AC, Garankina EV, Chizhova JN. Isotopic-geochemical composition of massive ground ice of Mordy-Yakha and se-Yakha (Mutnaya) interfluve (central Yamal). Arct Antarct. 2018;1(1):50-75. https://doi.org/10.7256/24538922.2018.1.25833

55. Leibman MO, Dvornikov YA, Khomutov AV, Kizyakov Al. Main results of four years gas-emission crater study. In: 5th European Conference of Permafrost. Chamonix, France; 2018.

56. Kokelj SV, Jenkins RE, Milburn D, Burn CR, Snow N. The influence of thermokarst disturbance on the water quality of small upland lakes, Mackenzie Delta region, Northwest Territories, Canada. Permafr Periglac Process. 2005;16(4):343-353. https://doi.org/10.1002/ ppp.536

57. Kuzin IL. Neotectonic Od West Sberian Oil- and Gas Province. Moscow, Russia: VINITI; 1982.

58. Bogoyavlenskiy VI, Sizov OS, Bogoyavlenskiy IV, Nikonov RA. Remote detection of surface gas releases in the Arctic: the Yamal peninsula. Arct Ecol Econ. 2016;3:4-15.

59. Dvornikov YA. The processes of thermodenudation in cryolithozone and the dissolved organic matter as their indication. 2016. http:// www.ikz.ru/wp-content/themes/ikz/images/dvornikov-full.pdf.

60. Kokelj SV, Lantz TC, Kanigan J, Smith SL, Coutts R. Origin and polycyclic behaviour of tundra thaw slumps, Mackenzie Delta region, Northwest Territories, Canada. Permafr Periglac Process. 2009;20(2):173-184. https://doi.org/10.1002/ppp.642

61. Hovland M, Judd AG, Burke RA. The global production of methane from shallow submarine sources. Cont Shelf Res. 1992;12(10):1231-1238. https://doi.org/10.1016/0045-6535(93)90442-8

62. Kling L, MacLean B. Pockmarks on the Scotian shelf. Geol Soc Am Bull. 1970;81(10):3141-3148. https://doi.org/10.1130/00167606(1970)81[3141:POTSS]2.0.CO;2

63. Hovland M, Judd AG. Seabed Pockmarks and Seepages: Impact on Geology, Biology and the Marine Environment. 1st ed. Dordrecht, the Netherlands: Springer; $1988 . \quad$ https://doi.org/10.13140/ RG.2.1.1414.1286

64. Portnov A, Mienert J, Winsborrow M, et al. Shallow carbon storage in ancient buried thermokarst in the South Kara Sea. Sci Rep. 2018;8(1):14342. https://doi.org/10.1038/s41598-018-32826-z

65. Paull CK, Ussler W, Dallimore SR, et al. Origin of pingo-like features on the Beaufort Sea shelf and their possible relationship to decomposing 
methane gas hydrates. Geophys Res Lett. 2007;34(1):L01603. https:// doi.org/10.1029/2006GL027977

66. Serov P, Portnov A, Mienert J, Semenov PB, llatovskaya P. Methane release from pingo-like features across the South Kara Sea shelf, an area of thawing offshore permafrost. Case Rep Med. 2015;120(8):1515-1529. https://doi.org/10.1002/2015JF003467

67. Bondarev VN, Rokos SI, Kostin DA, Dlugach AG, Polyakova NA. Underpermafrost accumulations of gas in the upper part of the sedimentary cover of the Pechora Sea. Geol Geophys. 2002;43(7):587-598.

68. Melnikov VP, Spesivtsev VI. Engineering-Geological and Geocryological Conditions of the Shelf of Barents and Kara Seas. Novosibirsk, Russia: Nauka; 1995.

69. Rokos SI, Kostin DA, Dlugach AG. Free gas and permafrost of the upper layer sediments of Kara- and Pechora Sea shallow shelves. In: Sedimentolog. Proc. and Marine Ecosys. Evolution in Marine Periglac. Cond. Apatity; 2001:40-51.

70. Are FE, Borovikova NV, Slepyshev VE. Cryopegs in the lower reaches of Yuribey river on Yamal. In: Nekrasov IA, ed. Linear Constructions on Permafrost. Moscow, Russia: Nauka; 1990:60-66.
71. Leibman MO, Khomutov AV, Gubarkov AA, Mullanurov DR, Dvornikov YA. The research station Vaskiny Dachi, central Yamal, West Siberia, Russia - a review of 25 years of permafrost studies. Fennia. 2015;193(1):3-30. https://doi.org/10.11143/45201

\section{SUPPORTING INFORMATION}

Additional supporting information may be found online in the Supporting Information section at the end of the article.

How to cite this article: Dvornikov YA, Leibman MO, Khomutov AV, et al. Gas-emission craters of the Yamal and Gydan peninsulas: A proposed mechanism for lake genesis and development of permafrost landscapes. Permafrost and Periglac Process. 2019;30:146-162. https://doi.org/10.1002/ $\underline{\text { ppp.2014 }}$ 